\title{
The Psychology of Contract Precautions
}

\author{
David A. Hoffman† \& Tess Wilkinson-Ryan ††
}

This research tests the intuition that parties to a contract approach each other differently before the contract is formed than they do once it is finalized. We argue that one of the most important determinants of self-protective behavior is whether the promisee considers herself to be in negotiations or already in an ongoing contract relationship. That shift affects precaution taking even when it has no practical bearing on the costs and benefits of self-protection: the moment of contracting is a reference point that frames the costs and benefits of taking precautions. We present the results of three questionnaire studies in which respondents indicate that they would be more likely to protect their own interests-by requesting a liquidated damages clause, by purchasing a warranty, or by shopping around to ensure the best deal-when the contract is not yet finalized than they would when they understand the agreement to be finalized. We discuss competing explanations for this phenomenon, including both prospect theory and cognitive dissonance. Finally, we explore some doctrinal implications for work on disclosure, modification, and promissory estoppel.

INTRODUCTION 396

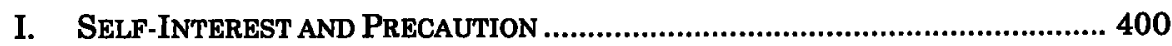

A. Defining Precautions .................................................................400

B. Why Not Take Precautions: The Economic Explanation .................. 403

C. Why Not Take Precautions: The Psychological Explanation ............ 405

D. Contract as Reference Point ........................................................406

II. EXPERIMENTAL EVIDENCE OF PRECAUTIONS ............................................ 408

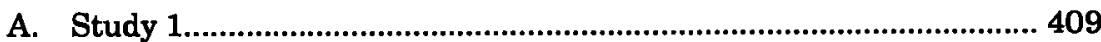

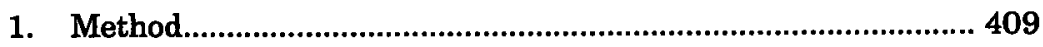

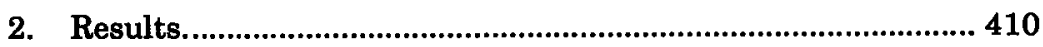

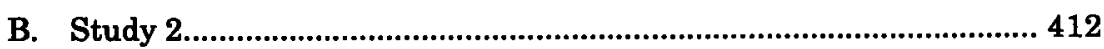

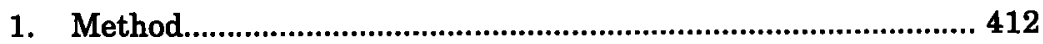

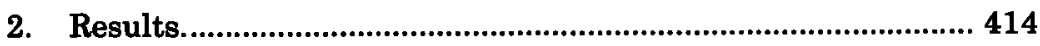

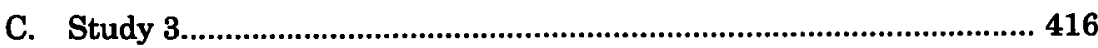

$\dagger$ James E. Beasley Professor of Law, Temple University Beasley School of Law. We thank Jane Baron, Craig Green, Zev Eigen, Yuval Feldman, Bob Hillman, Greg Mandel, Rafael Pardo, Alex Radus, Brishen Rogers, David Zaring, and participants at faculty colloquia at Vanderbilt Law School, the Wharton School at the University of Pennsylvania, University of Washington, William \& Mary Law School, as well as at the Conference on Empirical Legal Studies for comments on earlier drafts.

it Assistant Professor of Law, University of Pennsylvania Law School. 
1. Method

2. Results.

III. IMPLICATIONS FOR THE PSYCHOLOGY OF CONTRACT

A. Prospect Theory .......................................................................... 419

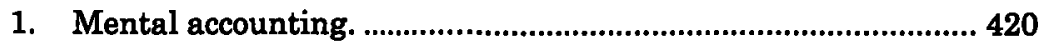

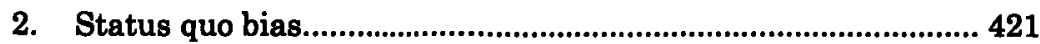

B. Relational Contracting and Overtrust ........................................... 422

C. Next Steps in the Psychology of Precautions.................................. 426

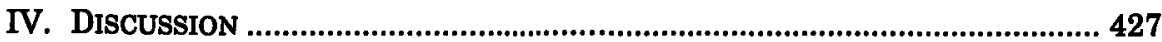

A. Reimagining Precautions............................................................. 428

B. Easy Cases: Good Faith and Modification ....................................... 429

C. Harder Cases: Disclosure and Promissory Estoppel ........................ 433

1. Which terms are in the deal? ................................................... 433

2. Promissory estoppel................................................................438 43

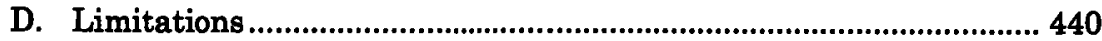

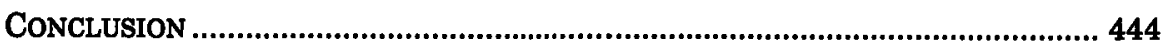

Before the contract is signed, the parties confront each other with a natural wariness. Neither expects the other to be particularly forthcoming, and therefore there is no deception when one is not. Afterwards the situation is different. The parties are now in a cooperative relationship the costs of which will be considerably reduced by a measure of trust. So each lowers his guard a bit, and now silence is more apt to be deceptive.

\section{Judge Richard Posner ${ }^{1}$}

\section{INTRODUCTION}

This Article explores one of the central tensions in contract law and policy: Are counterparties adversaries or partners? On the one hand, courts and lawmakers have worried for decades about parties' blithe willingness to make themselves vulnerable to exploitation. ${ }^{2}$ The first-year contracts course is populated by a

1 Market Street Associates Limited Partnership v Frey, 941 F2d 588, 594 (7th Cir 1991).

2 See Restatement (Second) of Contracts $\$ 90$ (1979) (providing a remedy for parties who reasonably relied on representations made by parties under an otherwise unenforceable agreement); Marco J. Jimenez, The Many Faces of Promissory Estoppel: An Empirical Analysis under the Restatement (Second) of Contracts, 57 UCLA L Rev 669, 671, 687-98 (2010) (examining over three hundred promissory estoppel cases over a twenty-six-year period to determine how judges conceive of equitable claims). 
parade of promisees who believe in contracts that do not exist, ${ }^{3}$ agree to outrageous terms that they could not possibly fulfill, 4 and over-rely on promises that leave them undercompensated when the promisor breaches. ${ }^{5}$ Even though most consumers would readily endorse the exhortation of caveat emptor, there is evidence that they fail to protect themselves across a variety of contractual dealings, with costly results. On the other hand, there are good reasons to think that overformalization and overprotection are harmful as well. Relying on social norms and interpersonal trust may actually be the most efficient approach for many kinds of contracts.

We approach the contract relationship from the perspective of the consumer or promisee and ask how and when individuals protect themselves from contractual harms including breach and exploitation. We hypothesize that one of the most important determinants of self-protective behavior is whether the promisee considers herself to be in negotiations or already in an ongoing contract relationship. That shift affects precaution taking even when it has no practical bearing on the costs and benefits of selfprotection. Put differently, the moment of contracting is a reference point: at moments before contracting, we take precautions against harm; afterward, we lower our defenses.

This research tests and expands on Judge Richard Posner's intuition, expressed in Market Street Associates LP $v$ Frey, ${ }^{6}$ that parties feel and act differently before and after entering contracts. ${ }^{7}$ We build on three interlocking scholarly traditions. First, there is a new literature on contracts as prospect theory reference points that frame the parties' judgments of the costs and benefits of the deal. ${ }^{8}$ Second, this reference point evidence

3 See, for example, Hoffman v Red Owl Stores, Inc, 133 NW2d 267, 275 (Wis 1965) (allowing damages in equity where the defendant encouraged the plaintiff to rely on its unenforceable promise).

4 See, for example, Williams $v$ Walker-Thomas Furniture Co, 350 F2d 445, 449 (DC Cir 1965) (holding that a contract can be invalidated if the terms are unreasonably favorable to one party and the other party's choice to enter the contract was not meaningful).

5 See, for example, Peevyhouse v Garland Coal \& Mining Co, 382 P2d 109, 114 (Okla 1962) (awarding damages equal to the diminution in market price of land where performance would be more costly than the value of the completed contract).

6941 F2d 588 (7th Cir 1991).

7 Id at 594.

8 See Oliver Hart and John Moore, Contracts as Reference Points, $123 \mathrm{Q} \mathrm{J}$ Econ 1, 5-13 (2008); Ernst Fehr, Oliver Hart, and Christian Zehnder, Contracts as Reference Points-Experimental Evidence, 101 Am Econ Rev 493, 518-22 (2011); Yuval Feldman, Amos Schurr, and Doron Teichman, Reference Points and Contractual Choices: An Empirical Examination `25, 28 (working paper, Jan 21, 2012), online at 
complements the powerful relational contracting literature, which argues that commercial parties behave as if long-term contracts are partnerships and often forgo legal opportunities to take exploitative gains. ${ }^{9}$ Third, the growing understanding that individuals perceive contracts as a set of bilateral moral commitments, rather than merely options to pay or perform, strongly suggests that lay people believe that contract formation has moral implications. ${ }^{10}$

Understanding contract formation as a reference point sheds new light on several important live problems in contract doctrine and policy. For example, there is a growing field of scholarship worrying about the common practice of unilateral modifications in common consumer contracts. As Professor David Horton shows, credit card companies were able to roll out arbitration clauses as modifications to existing contracts, overcoming initial court resistance through sophisticated lawyering. " This has been deemed worrisome enough that Professors Oren Bar-Gill and Kevin Davis have proposed a third-party monitoring mechanism to remedy such unpoliced, unilateral modifications, the "Change Approval Board."12 Professors Peter Alces and Michael Greenfield have collected examples of unilateral modifications across multiple consumer channels and argued that courts should reinvigorate the doctrine of good faith. ${ }^{13}$ These kinds of proposals are motivated by the sense that unilateral modifications are unlikely to be welfare maximizing and that they often exploit consumers' cognitive biases. ${ }^{14}$ But it has been unclear exactly which cognitive biases affect a consumer's

http://papers.ssrn.com/sol3/papers.cfm?abstract_id=1989556 (visited Mar 3, 2013) (finding that framing payoffs as losses tends to encourage self-serving interpretation of contract language).

9 See text accompanying notes 85-86.

10 See Part III.C.

11 David Horton, The Shadow Terms: Contract Procedure and Unilateral Amendments, 57 UCLA L Rev 605, 630-31 (2010); David Horton, Arbitration as Delegation, 86 NYU L Rev 437, 458-59 (2011).

12 Oren Bar-Gill and Kevin Davis, Empty Promises, 84 S Cal L Rev 1, 37 (2010).

13 Peter A. Alces and Michael M. Greenfield, They Can Do What!? Limitations on the Use of Change-of-Terms Clauses, $26 \mathrm{Ga}$ St U L Rev 1099, 1101-06, 1145 (2010).

14 See Bar-Gill and Davis, $84 \mathrm{~S}$ Cal L Rev at 20 (cited in note 12) ("[M]ost consumers are imperfectly informed or imperfectly rational, and as a result they misperceive the risk of unilateral modifications."); Horton, 57 UCLA L Rev at 648 (cited in note 11) ("[T] $]$ here is growing acceptance that bounded rationality prevents even informed adherents from making welfare-maximizing choices."). 
ability to evaluate modifications. ${ }^{15}$ What's so psychologically special about unilateral modification? Our research situates the problem of assent to modification within the broader class of contracts decisions that people approach skeptically outside of contract but readily accept once the main agreement has been signed.

The approach advocated here also bears on a related debate over the merits of mandatory term disclosure. Armed with evidence that consumers essentially never read licenses, contracts, or warranties, opponents of mandatory disclosure have begun to make inroads against one of the most popular regulatory approaches to voluntary transactions. ${ }^{16}$ Others defend disclosure, arguing that it is a cheap and harmless foundation for enforcement. ${ }^{17}$ We suggest that consumers see the relevant terms differently depending on when they are presented. Many of the most controversial cases tug at the intuition that terms that follow formation-think Carnival Cruise Lines, Inc v Shute ${ }^{18-a r e}$ particularly problematic. Once parties understand that the contract has been formed, they are especially unlikely to take care. In fact, clever promisors might be able to manipulate precautionary behavior by making the most salient moment of contracting (for example, signing forms or exchanging a good for money) precede revelations of objectionable terms. In that way, firms can reduce the likelihood that the consumers will engage in self-protective behavior like reading the contract, or shopping around, without exposing themselves to legal sanctions. As such, reference point theory exposes how contract law's relentlessly objective focus could permit sophisticated parties to manipulate the timing of disclosures without offending the legal requirement of mutual assent.

In some ways, the idea that formation reorients parties' expectations seems so anodyne that it may not warrant empirical investigation. However, this Article not only demonstrates that

15 See Horton, 57 UCLA L Rev at 646-48 (cited in note 11) (attributing inefficiency in consumers' decisions to the failure to read the terms at issue, unreasonable optimism, and irrationality).

16 See, for example, Omri Ben-Shahar and Carl E. Schneider, The Failure of Mandated Disclosure, 159 U Pa L Rev 647, 665 (2011); Omri Ben-Shahar, The Myth of the 'Opportunity to Read' in Contract Law, 5 Eur Rev Contemp L 1, 13-21 (2009); Ronald J. Mann and Travis Siebeneicher, Just One Click: The Reality of Internet Retail Contracting, 108 Colum L Rev 984, 998-1001 (2008).

17 See, for example, Robert A. Hillman and Maureen O'Rourke, Defending Disclosure in Software Licensing, 78 U Chi L Rev 95, 106-08 (2011).

18499 US 585 (1991). 
the intuition has bite across an array of precautionary decisions but also that it cannot be explained by straightforward analysis of economic costs and benefits, even when we take into account transaction costs. We proceed as follows. In Part I of this Article, we argue that the extant literature on self-protective behavior by contracting parties, loosely organized around the term "precautions," ignores the psychological dimensions of self-protection in contract, and we suggest that existing behavioral evidence helps explain why contract formation might affect precautions.

In Part II, we present the results of three questionnaire studies in which respondents indicate that they would be more likely to protect their own interests-via a liquidated damages clause, warranty, or shopping around-when the contract is under negotiation than they would when they understand the agreement to be finalized. Our goal in this experimental series is to control for economic justifications for Judge Posner's intuition, including transaction costs and the anticipated legal remedies that parties might obtain in contracts (rather than in negotiations). We are left with a decrease in precautionary behavior contingent on the promisee's belief that a contract has been formed, a phenomenon that cannot be easily explained by the economic incentives.

In Part III, we draw lessons from existing psychology and experimental economics research and consider their applications to the contracts context. Research on prospect theory, particularly on loss aversion and the status quo bias, may help explain why parties might be willing to expend resources before the contract is signed but be reluctant to incur what they perceive as an additional loss once the deal is done. We also consider the possibility, bolstered by research on cognitive dissonance and confirmation bias, that people implicitly or explicitly subscribe to a behavioral rule of thumb that favors wariness in the selection phase of contract and trust in the execution phase. Finally, in Part IV, we lay out some of the real-world applications of our findings and discuss the limitations of our work.

\section{SELF-INTEREST AND PRECAUTION}

\section{A. Defining Precautions}

This Article is about how and when parties, promisees in particular, take precautions in contract. As a general matter, when we think about contract precautions, the examples that 
come easily to mind are the protections against breach taken by commercial actors. Developers purchase insurance against construction delays; companies monitor workers to guard against shirking; retailers source goods from multiple manufacturers to reduce the harm of any one problem in the supply chain. ${ }^{19}$ These examples lend themselves nicely to economic or game theoretic analyses of optimal precaution taking, ${ }^{20}$ but they give the false impression that precautions are relevant only for a small fraction of contracts.

Ordinary consumers make many choices about investing in precautions. Precautions can be general or specific. Health and homeowners insurance remediate injuries (including ones generated by breach) that the law may undercompensate; customers purchase shipping insurance to supplement the declared value of their packages.21 Typically, however, formal insurance against breach is relatively expensive for the promisee to purchase, in part because it is so difficult to monitor the promisor's behavior. ${ }^{22}$ There is also evidence that individuals typically are underinsured against catastrophic breaches, in part because of the kinds of decision biases that we explore later in this paper. ${ }^{23}$

19 See David Campbell, A Relational Critigue of the Third Restatement of Restitution $\$ 39,68$ Wash \& Lee L Rev 1063, 1112 (2011) (explaining that a potential plaintiff may wish to minimize the risk of loss from breach by obtaining additional insurance or contracting with multiple suppliers); Stephen M. Bainbridge, Privately Ordered Participatory Management: An Organizational Failures Analysis, 23 Del J Corp L 979, 1009 (1998) ("[M]anagers . . . are tasked with monitoring the organization's members. Management meters the marginal productivity of each member and responds as necessary to prevent shirking."). See also Terrance L. Brennan, Construction Insurance: A General Perspective, 15 Construction Law 1, 45 (1995) (emphasizing the importance in construction of insuring against delays). But see Alan Schwartz, The Case for Specific Performance, 89 Yale L J 271, 277 (1979) ("'W] dered over time, as in construction or requirements contracts, it is costly for the promisee to monitor a reluctant promisor's conduct.").

20 See, for example, George S. Geis, An Experiment in the Optimal Precision of Contract Default Rules, 80 Tulane L Rev 1109, 1149-55, 1158 (2006) (arguing that default rules could be mapped onto efficient precautions parties take during negotiations).

21 See, for example, Shipping Insurance Coverage (Shipsurance), online at http:// www.shipsurance.com/shipping_insurance.asp (visited Mar 3, 2013).

22 See Steve Thel and Peter Siegelman, You Do Have to Keep Your Promises: A Disgorgement Theory of Contract Remedies, $52 \mathrm{Wm}$ \& Mary L Rev 1181, 1231 (2011). Impracticability is often cited as an example of the interplay between the promisee's insurance (or lack of it) and the promisor's discharge. See Richard A. Posner and Andrew M. Rosenfield, Impossibility and Related Doctrines in Contract Law: An Economic Analysis, 6 J Legal Stud 83, 92 (1977).

23 See Howard Kunreuther, Robert Meyer, and Erwann Michel-Kerjan, Overcoming Decision Biases to Reduce Losses from Natural Catastrophes, in Eldar Shafir, ed, Behavioral Foundations of Public Policy 398, 401-08, 411 (Princeton 2013). 
Promisees can also take precautions that are internal to the contractual relationship. Before contracting, they can select against the likelihood of breach using various methods: thirdparty providers, social connections, evidence of brand strength, or face-to-face signals of trustworthiness. ${ }^{24}$ When they perceive their counterparties to be less trustworthy, they may pay less for performance. ${ }^{25}$ Or promisees can ask for contractual terms that will reduce the likelihood of breach or the harm that it will cause, or that will increase the damages that the law permits. ${ }^{26}$ Alternatively, they may invest less in reliance on the contract. ${ }^{27}$

Later in this Article, we suggest that promisees might take precautions against counterparty actions that don't rise to the level of legal breach. Before doing so, we first ask how legal economists have approached the problem of guarding oneself against actions that the law also remedies.

24 See Howard Latin, "Good" Warnings, Bad Products, and Cognitive Limitations, 41 UCLA L Rev 1193, 1219 (1994) (explaining that manufacturers heavily invest in branding in order to create a positive reputation on which consumers will rely); Oren Bar-Gill, The Behavioral Economics of Consumer Contracts, 92 Minn L Rev 749, 755-56 (2008); Bruce Lyons and Judith Mehta, Contracts, Opportunism and Trust: Self-Interest and Social Orientation, 21 Camb J Econ 239, 250 (1997); Campbell, 68 Wash \& Lee L Rev at 1112 (cited in note 19).

25 But see Campbell, 68 Wash \& Lee L Rev at 1112 (cited in note 19) ("Now, if the risk of idiosyncratic loss is high, the potential plaintiff may pay the higher price for [the good for which the party is contracting], because the extra security, and ultimately extra precaution, will be of value to him.").

26 See Lucian Arye Bebchuk and Steven Shavell, Information and the Scope of Liability for Breach of Contract: The Rule of Hadley v. Baxendale, $7 \mathrm{~J} \mathrm{~L}$, Econ, \& Org 284, 286, 296 (1991). See also FedEx Express Terms and Conditions: U.S. Shipments 6 (FedEx Oct 2, 2012), online at http://images.fedex.com/us/services/pdf/SG_TermsCond_US_2012.pdf (visited Mar 3, 2013):

The declared value of any package represents our maximum liability in connection with a shipment of that package, including, but not limited to, any loss, damage, delay, misdelivery, nondelivery, misinformation, any failure to provide information, or misdelivery of information relating to the shipment. It is the shipper's responsibility to prove actual damages. Exposure to and risk of any loss in excess of the declared value is assumed by the shipper. You may transfer this risk to an insurance carrier of your choice through the purchase of an insurance policy. Contact an insurance agent or broker if you desire insurance coverage. WE DO NOT PROVIDE INSURANCE COVERAGE OF ANY KIND.

27 See Francesco Parisi, Barbara Luppi, and Vincy Fon, Optimal Remedies for Bilateral Contracts, $40 \mathrm{~J}$ Legal Stud 245, 249 (2011) (explaining that in some bilateral contracts parties who do not trust that the other contracting party will perform have an incentive to withhold performance rather than invest in the contract); Amitai Aviram, Regulation by Networks, 2003 BYU L Rev 1179, 1185. 
B. Why Not Take Precautions: The Economic Explanation

Most discussions of precautions ask when self-protection against breach is economically justified. The literature on optimal precautions in the law and economics tradition is well developed, ${ }^{28}$ noted for its sophistication but criticized for its indeterminacy. ${ }^{29}$ It generally focuses on the complex relationship between the default rule of damages (reliance or expectation) and how much the parties will invest in the bargain after it has been made. ${ }^{30}$ The idea is that people will take precautions if they think that they will be undercompensated in the event of breach. Authors usually assume risk neutrality, perfect information, rational parties, and fully compensatory damage regimes. ${ }^{31}$ Under these assumptions, we may generally expect that parties will invest in precautions in ways that do not maximize their joint welfare. In particular, we expect moral hazard.

Both the expectation and the reliance measures of damages may cause the promisee who anticipates breach to rely too much and take too few precautions..$^{32}$ That is, because the promisee is in effect insured against losses by contract damages, she will overinvest in her own performance and turn an efficient bargain into one the promisor would not have originally entered into. Conversely, the promisor may spend less to prevent breach than is otherwise optimal. ${ }^{33}$ Thus, if parties are unable to modify the default regime, damage remedies inevitably will cause one of the parties to behave inefficiently.

This relationship between precautions and damages has particularly stark implications for precontractual reliance. ${ }^{34}$

28 For a useful summary of the literature on optimal precautions, see Richard Craswell, The "Incomplete Contracts" Literature and Efficient Precautions, 56 Case W Res L Rev 151, 159-62 (2005).

29 For a classic statement of the indeterminacy position, see Eric A. Posner, Economic Analysis of Contract Law after Three Decades: Success or Failure?, 112 Yale L J 829, 836-39 (2003).

30 Typically in the literature, authors take promisors' precautions to be investments to avoid breach, while the promisees' precautions are the amount that it relies on the bargain. See, for example, George M. Cohen, The Fault Lines in Contract Damages, 80 Va L Rev 1225, 1234-35 (1994).

31 See, for example, Steven Shavell, Damage Measures for Breach of Contract, 11 Bell J Econ 466, 469-70 (1980).

32 See id at 471-72.

33 See Robert Cooter, Unity in Tort, Contract and Property: The Model of Precaution, 73 Cal L Rev 1, 12-13 (1985) (describing the effect as a result of externalizing the costs of breach).

34 For a helpful summary and critique of the literature, see Ofer Grosskopf and Barak Medina, Regulating Contract Formation: Precontractual Reliance, Sunk Costs, 
Generally, given that contract doctrine purportedly rarely compensates precontract reliance, ${ }^{35}$ parties will be motivated to invest less in precontract investigation than they otherwise would. Thus, scholars argue that the law encourages moral hazard and opportunism by promisors. ${ }^{36}$ In this vein, Professor Richard Craswell has argued that selection is an important precontractual precaution; the promisee might select away from risky promisors as a form of precaution against breach. ${ }^{37}$ Where buyers and sellers are perfectly informed, of course, the law's remedies will not influence such selection decisions. ${ }^{38}$ However, where the promisee is imperfectly aware of the risk of the promisor's breach-as will almost always be the case-the situation is more complex. As such imperfectly informed promisees bear more risk of breach, they will be more risk averse and will buy more expensive precautions (so long as they are aware of their lack of knowledge); conversely, their counterparties will be more risk seeking. ${ }^{39}$ The consensus is that these insights about the relationship between doctrine and efficiency ought to lead to changes in the former to encourage promisee precaution taking ${ }^{40}$ such as, for example, a more rigorous disclosure regime. ${ }^{41}$

The account that we offer here is not necessarily in tension with the economic literature because our focus is on a phenomenon that the economic account ignores altogether. We suggest that individuals approach the same self-protective decision-

and Market Structure, 39 Conn L Rev 1977, 1985-95 (2007). For two classic papers, see Richard Craswell, Precontractual Investigation as an Optimal Precaution Problem, $17 \mathrm{~J}$ Legal Stud 401, 402, 420 (1988) (addressing the effect of various damage measures on the parties' incentives to gather information prior to contracting); Lucian Arye Bebchuk and Omri Ben-Shahar, Precontractual Reliance, $30 \mathrm{~J}$ Legal Stud 423, 424 (2001).

35 But see Anglia Television Ltd v Reed, [1972] 1 QB 60, 64 (Ct App 1971).

36 See, for example, Juliet P. Kostritsky, Bargaining with Uncertainty, Moral Hazard and Sunk Costs: A Default Rule for Precontractual Negotiations, 44 Hastings L J 621, 635-41 (1993); G. Richard Shell, Opportunism and Trust in the Negotiation of Commercial Contracts: Toward a New Cause of Action, 44 Vand L Rev 221, 251-64 (1991).

37 Richard Craswell, Contract Remedies, Renegotiation, and the Theory of Efficient Breach, 61 S Cal L Rev 629, 652 (1988).

38 Id at 653-56.

39 See id at 659-61; Richard Craswell, Instrumental Theories of Compensation: $A$ Survey, 40 San Diego L Rev 1135, 1163-65 (2003) (discussing both selection and risk investigation as a form of precaution).

40 See, for example, Omri Ben-Shahar, Contracts without Consent: Exploring a New Basis for Contractual Liability, $152 \mathrm{U} \mathrm{Pa} \mathrm{L} \mathrm{Rev} \mathrm{1829,} \mathrm{1851-52} \mathrm{(2004)} \mathrm{("[T]} \mathrm{he} \mathrm{no-}$ retraction regime improves the parties' incentives to make precontractual investments."); Cohen, 80 Va L Rev at 1251-55 (cited in note 30) (discussing how courts might infuse promisee's fault into doctrine as a way of setting optimal precautions).

41 See Melvin A. Eisenberg, Disclosure in Contract Law, 91 Cal L Rev 1645, 1649 56 (2003). 
buying a warranty, for example-differently depending on whether they perceive the main contract to have been formed or not. The warranty itself is a precaution that only takes effect once the contract has been made, which means that the decision in either case assumes a world in which the contract exists. The reference point, then, is about when parties are making the precautions decision, before or after the core deal is made. That is, we are not asking subjects to distinguish between precautions that will be treated differently by the law. In fact, we readily agree that the availability of remedies affects how promisees will act, but we are arguing that even holding remedies constant, individuals are more protective when they are negotiating than when they are within the contract.

\section{Why Not Take Precautions: The Psychological Explanation}

Sometimes precautions are costly because they take a toll on the contract relationship. Asking for a liquidated damages clause communicates concern about breach, on the one hand, and a willingness to put a price on breach (thus perhaps destigmatizing it), on the other. ${ }^{42}$ Monitoring one's counterparty communicates distrust. Not only is this a potentially uncomfortable thing for the monitoring party to do, it often has the result of decreasing the monitored party's efforts. ${ }^{43}$ Parties subject to monitoring often report that the restriction on freedom and the sense of distrust instantiate an essentially spiteful response-the lack of trust is aggravating enough that they respond by behaving in an untrustworthy manner. ${ }^{4}$

Indeed, the social and psychological pressures against precaution taking have already been studied in the context of conflict-of-interest disclosures. When one party in a transaction reveals that she has a conflict of interest, how does it affect the other party's choices? Professors Daylian Cain, George Loewenstein, and Don Moore found that the disclosure of conflicts leads to exaggeration by advisors and little discounting by advisees. ${ }^{45}$

42 See Tess Wilkinson-Ryan, Do Liquidated Damages Encourage Breach? A Psychological Experiment, 108 Mich L Rev 633, 637, 655, 663-64 (2010).

43 See Bruno S. Frey, Does Monitoring Increase Work Effort? The Rivalry with Trust and Loyalty, 31 Econ Inq 663, 664-66 (1993).

44 See Armin Falk and Michael Kosfeld, The Hidden Costs of Control, 96 Am Econ Rev 1611, 1611, 1617-22 (2006).

45 Daylian M. Cain, George Loewenstein, and Don A. Moore, The Dirt on Coming Clean: Perverse Effects of Disclosing Conflicts of Interest, 34 J Leg Stud 1, 5-7, 12-14, 17 (2005); Daylian M. Cain, George Loewenstein, and Don A. Moore, When Sunlight Fails to 
In fact, some advisees appear to trust a discloser even more, reasoning that the disclosure itself is evidence of trustworthiness. ${ }^{46}$ Even when advisees do not actually feel greater trust toward a discloser, there is some evidence that advice recipients feel increased pressure to comply with advice that is accompanied by a disclosure because they feel "insinuation anxiety." 47 The idea is that when one receives advice and then a sheepish disclosure of a conflict along with reassurance that the underlying belief in the advice is true, the advisee is put in an odd position. Rejection of the recommendation may convey to the advisor that the advisee is suspicious of his motives or worries that he has been corrupted. ${ }^{48} \mathrm{Or}$, even more basically, advisees may feel obligated to help the advisor out-choosing against the advisor's interest may feel rude. ${ }^{49}$ Couched in the terms of this Article, this means that advisees fail to protect themselves when they are worried that doing so is offensive. The analogy to the contracts context puts promisees in the advisee position. Taking precautions against a promisor may be uncomfortable or even counterproductive because doing so communicates a lack of trust.

\section{Contract as Reference Point}

In this paper, we accept both the economic and the interpersonal costs of precaution taking but suggest that the timing of the precaution-taking opportunity (before or after formation) affects decision making even holding these costs constant. The idea that contract formation is a reference point for judgment is one that has had some traction in other areas of contract scholarship. Professor Daniel Kahneman and his coauthors argued that to evaluate the fairness of a set of contract terms (described not as a contract but as "actions in which a firm sets the terms of future exchanges"), individuals look to the reference transaction-any exchange that sets a salient precedent for the one

Disinfect: Understanding the Perverse Effects of Disclosing Conflicts of Interest, $37 \mathrm{~J}$ Consumer Rsrch 836, 849-51 (2011).

46 See Cain, Loewenstein, and Moore, $34 \mathrm{~J} \mathrm{Leg} \mathrm{Stud} \mathrm{at} \mathrm{5-6} \mathrm{(cited} \mathrm{in} \mathrm{note} \mathrm{45)} \mathrm{("Indeed,}$ it is even possible that disclosure could sometimes increase rather than decrease trust, especially if the person with the conflict of interest is the one who issues the disclosure.").

47 Sunita Sah, George Loewenstein, and Daylian M. Cain, The Burden of Disclosure: Increased Compliance with Distrusted Advice *6 (working paper, Dec 7, 2011), online at http://papers.ssrn.com/sol3/papers.cfm?abstract_id=1615025 (visited Mar 3, 2013).

48 See id ("Under these circumstances, disclosure effectively puts the advisees in a bind; they distrust the advice but also feel pressured to comply with it.").

49 See id. 
being assessed. 50 This has important implications for what kinds of contractual behavior people find acceptable. Professor Kahneman and others found, for example, that individuals deem lowering employee wages in the face of increased labor supply unfair, since the employee's current wage serves as the reference transaction against which wage adjustments are measured. ${ }^{51}$ But individuals perceive hiring new employees at a lower wage as largely unproblematic because those employees are not party to the reference transaction between the old employees and the firm. ${ }^{52}$ The idea of the reference transaction is that the contract terms become a reference point that in turn frames parties' perceptions of their obligations and vulnerabilities in an exchange. ${ }^{53}$

Professors Oliver Hart and John Moore recently applied this observation to contracts even more explicitly, arguing that contracts are reference points that define how parties evaluate outcomes. ${ }^{54}$ In a set of behavioral experiments, Professors Ernst Fehr, Oliver Hart, and Christian Zehnder found that contracts that build in an otherwise efficient level of flexibility may have the effect of disappointing expectations and overall reducing profits. ${ }^{56}$ Professors Fehr, Hart, and Zehnder allowed players in an experimental game to choose either a flexible contract or a rigid contract. ${ }^{66}$ Players did not know what the state of the world would be at the time of trading-that is, they did not know what the market value of the traded good would be. ${ }^{57}$ The flexible contract permitted many different outcomes based on the buyer's choice once she learned the market rate. ${ }^{58}$ The rigid contract

50 Daniel Kahneman, Jack L. Knetsch, and Richard Thaler, Fairness as a Constraint on Profit Seeking: Entitlements in the Market, 76 Am Econ Rev 728, 729 (1986).

51 Id at $729-30$.

52 Id at 730 ("For new transactions, prevailing competitive prices or wages provide the natural reference.").

53 Id at 729.

54 Hart and Moore, 123 Q J Econ at 2, 10-11 (cited in note 8).

65 Fehr, Hart, and Zehnder, 101 Am Econ Rev at 494 (cited in note 8) ("A flexible contract is good in that parties can adjust to the state of nature, but bad in that there can be a lot of aggrievement and shading."). See also Hart and Moore, $123 \mathrm{Q} \mathrm{J}$ Econ at 4 (cited in note 8) ("A flexible contract has the advantage that parties can adjust the outcome to the state of the world, but the disadvantage that any outcome selected will typically cause at least one party to feel aggrieved and shortchanged, which leads to a loss of surplus from shading.").

56 Fehr, Hart, and Zehnder, 101 Am Econ Rev at 498 (cited in note 8) (giving experimental buyers the ability to choose either a rigid contract, under which the price is fixed at the time of contracting, or a flexible contract, under which the buyer can, at the time of exchange, choose from a range of prices).

57 Id at $498-99$.

58 Id at 498. 
permitted a single outcome, also determined by the buyer, decided at the moment of drafting. 59

Sellers had the option of "shading," or paying a small amount to reduce the buyer's profit. ${ }^{60} \mathrm{We}$ can think of this as the seller's opportunity to punish the buyer for bad behavior. Sellers who got very little of the joint surplus when the contract was rigid very rarely engaged in shading. ${ }^{61}$ Sellers who got the same kind of deal when the contract was flexible were significantly more likely to shade (another way of saying that they engaged in a form of costly punishment). ${ }^{62}$ Notice that sellers did not punish buyers for offering the original bad deal; they only punished buyers for the bad deal when the contract appeared to allow for a good deal. The reference point was the contract, meaning the value of performance was judged with reference not to the overall outcome but with reference to the expected outcome under the contract. ${ }^{63}$

\section{EXPERIMENTAL EVIDENCE OF PRECAUTIONS}

The studies reported below draw on each of the literatures reviewed in Part I. In line with the reference point theory, we predict that people will treat precaution-taking decisions differently when they are in a contract already rather than when they are still negotiating. In real life, one reason for this may be drawn from the social psychology literature: people are less willing to be self-interested within the context of the contract relationship because they do not want to offend the other party. ${ }^{64}$ Here, the scenarios we use are designed to exclude actual costs that might come from relational harms caused by the precautions. Furthermore, we predict that parties will evaluate both the psychological and the financial appeal of precautions in light of the existence, or not, of the contract.

In this Part, we investigate the hypothesis that the perceived costs of precautions are evaluated differently based on

69 Id.

60 Fehr, Hart, and Zehnder, 101 Am Econ Rev at 499 (cited in note 8).

61 Id at 507.

62 Id at 519.

63 Id at 521. See also Feldman, Schurr, and Teichman, Reference Points and Contractual Choices at *28 (cited in note 8 ) (finding similar results in experiments focusing on the parties' interpretation of their contractual commitment).

64 See notes $47-49$ and accompanying text. 
whether parties are in precontractual negotiations or parties are in a contractual commitment.

\section{A. Study 1}

1. Method.

This experiment tested the hypothesis that subjects would be more likely to request a liquidated damages clause, a fairly common form of contractual precaution, ${ }^{65}$ in the negotiation phase of contracting rather than after the contract had been signed. We showed subjects one of two versions of a contract scenario. In one version, they were asked to imagine that they were still in the drafting stage; in the other version, they had already signed the contract but could add a rider to the contract. In each case, subjects are told that the basic contract has already been worked out and that they have received new information that might encourage them to get additional guarantees. The only difference between the scenarios is whether the basic exchange has been formalized in a signed contract or not. Here is the first scenario:

You need to hire help to move you out of your home. You approach Pack-n-Go Corporation, a moving firm. The cost of the Pack-n-Go Total Moving Package is $\$ 3,000$. Two experienced movers and one trainee will be assigned to your job. Based on your research, Pack-n-Go's prices are very competitive for the kind of move you are contemplating.

65 See Restatement (Second) of Contracts \$ 356, comment a (explaining that a liquidated damages clause can save parties time and money in the event of breach). 


\section{STUDY 1. ANTIQUe PIANO STUDY}

Contract

\begin{abstract}
After you have signed the contract, you start to get some of your bigger items appraised. This includes an old grand piano. You thought the piano was worth $\$ 1,000$ or so, but it turns out it is worth almost $\$ 4,000$. You are somewhat worried about damage during the move.
\end{abstract}

How likely would you be to call the company to negotiate for extra protection for the piano? One option is to ask the moving company to include a rider, a modification, to your contract laying out the amount that the movers will pay in the event of damage. How likely are you to ask for this kind of clause to be added to the agreement?
No Contract

As you begin to negotiate the moving contract, you start to get some of your bigger items appraised. This includes an old grand piano. You thought the piano was worth $\$ 1,000$ or so, but it turns out it is worth almost $\$ 4,000$. You are somewhat worried about damage during the move.

During the contract negotiations, how likely would you be to negotiate for extra protection for the piano? One option is to ask the moving company to include a specific provision in the contract laying out the amount that the movers will pay in the event of damage. How likely are you to ask for this kind of clause during the negotiation?

\section{Results.}

Subjects were recruited on Amazon Mechanical Turk.66 They were paid seventy cents for answering a five-minute survey. There were 209 subjects in the Contract condition, and 201 in the No Contract condition. Sixty percent of subjects were female. Subject ages ranged from eighteen to eighty-eight, with a median age of twenty-nine.

The hypothesis was that subjects would report that they were more willing to ask for a liquidated damages clause in the No Contract condition than in the Contract condition, and that prediction was reflected in the results. On a 7-point scale (where 7 was "very likely" and 1 was "very unlikely") the average interest in the clause for subjects in the No Contract group was 5.52; the average for subjects in the contract group was 5.00. This difference is highly significant $(W=16864.5, p=0.0004) .{ }^{67}$ Because

66 For more details regarding Amazon's Mechanical Turk, see Amazon Mechanical Turk (Amazon Web Services), online at http://aws.amazon.com/mturk (visited Mar 3, 2013).

67 Nonparametric tests of statistical significance like the one used here (the Wilcoxon test) are common when sample sizes are small and when the distribution is nonnormal. The tests are typically less powerful but more robust than parametric tests like the $t$ - or $F$-statistics. One study reported here uses a small sample. For consistency, we 
it can be hard to interpret the magnitude of the effect by looking only at the mean difference, we also compared the subjects' interest in the clause in terms of percentages-for example, what proportion of subjects in each group thought they would be likely to ask for the liquidated damages clause? We compared how many subjects said that they would be likely to ask for the clause (a rating of 5,6 , or 7 ) by condition. Seventy-nine percent of subjects said they would be likely to ask for the clause in the No Contract condition versus 67 percent in the Contract condition $(W=18664, p=0.011$ ). Similarly, 25 percent of the No Contract subjects reported that they would be "very likely" to ask for a liquidated damages clause, but only 19 percent said the same in the Contract condition ( $W=19385.5, p=0.062$ ).

This study found support for the basic proposition that subjects were more open to the idea of requesting a liquidated damages clause when the contract was not yet finalized. The goal of these studies is to test the hypothesis that people change their stance away from precaution taking when they enter a contract, even when there is no efficiency rationale for such a behavioral shift. This initial study offers some preliminary evidence in support of the hypothesis, but there are alternative explanations for the pattern of responses that we would like to rule out in subsequent studies. We flag three possibilities:

(1) Subjects may believe that the moving company would be more willing to add the liquidated damages clause during the negotiation than after, which could mean that the clause would be less costly if added during negotiations (though the scenario was written to suggest that the contract price is set) or simply that the other party would be more likely to refuse the request. 68

(2) It is conceivable that subjects could imagine that it is more costly to get a rider to a contract than to negotiate the clause upfront-perhaps because it means getting lawyers back in a room together or undergoing some kind of

report the $p$-values generated by the nonparametric test in all three studies. See Robert Rosenthal and Ralph L. Rosnow, Essentials of Behavioral Research: Method and Data Analysis 403-04 (McGraw-Hill 3d ed 2008).

68 Subjects may even think that adding a rider is impermissible. Professor Larry Cunningham has noted that one of the most prevalent misconceptions about contracts is that they cannot be modified. See Lawrence A. Cunningham, Contracts in the Real World: Stories of Popular Contracts and Why They Matter 170-71 (Cambridge 2012) (correcting the misconception that "contracts cannot be changed once they are made"). 
additional formalization of the new term. ${ }^{69}$ The scenario is not written to suggest that lawyers will be involved or that the contract is formal enough that adding the rider would require substantial extra effort, but this reading is not implausible.

(3) Subjects may imagine that raising the precaution issue later in the contract relationship is more offensive to the moving company, and that, as such, they are more likely to shirk or retaliate in ways that could not be adequately monitored or fully compensated.

Studies 2 and 3 were written to minimize the relevance of these explanations for the proffered result by reimagining the role of precaution taking in the promisor-promisee relationship. The kinds of precautions that come to mind most readily are those that are made known to the promisor and perhaps even affect his rights and obligations under the contract (like a liquidated damages clause or a warranty clause in the contract), or at least the logistics of performance. But many precautions need not affect the promisor at all. A promisee might discreetly monitor a construction site when the crew is gone for the night. She might discreetly leave a "nanny cam" on to watch a babysitter perform or take a contract home to read its terms carefully. These are all self-protective maneuvers that happen outside the promisor's awareness. Studies 2 and 3 invoke precautionary decisions that occur outside the contract dealings and are thus less likely to impose real costs, whether in the form of transaction costs or the costs of dealing with an offended counterparty.

\section{B. Study 2}

1. Method.

In Study 2, our hypothesis is that subjects will be more likely to buy a warranty before purchase than after purchase ("purchase" here being the moment of contractual agreement). This study was also conducted using Amazon Turk participants and using the same subject pool as that in Study 1. Subjects were

69 See Kevin E. Davis, The Demand for Immutable Contracts: Another Look at the Law and Economics of Contract Modifications, 81 NYU L Rev 487, 496 (2006) (suggesting that one problem with creating incentives for renegotiation is that renegotiating incurs additional costs while "redistribut[ing], rather than creat[ing], value"). 
shown one of two versions of an eBay transaction and asked to report whether they would be inclined to purchase an extra warranty and how much they would be willing to pay for it. In this case, the warranty is being offered by a third party, such that subjects do not infer that the warranty offer is a signal by the seller. Subjects in each condition were given identical information about the hypothetical seller. Finally, in the two conditions, subjects are meant to understand that the underlying deal is a fait accompli. In the Contract case, payment has already been submitted. In the other, subjects are told that they have already made up their minds to buy the car but that payment has not been submitted. As in Study 1, the scenarios are designed to make clear to subjects that, in both cases, the underlying deal is going through at a price that has already been set and that the precaution is an add-on. In this case, the add-on does not actually affect the contract, in the sense that it is a separate deal with a third party. The scenario reads as follows:

Please imagine that you are in the market to purchase a particular make and model of used car: a 2003 Volkswagen Beetle, preferably in blue. Kelley Blue Book value of this car in excellent condition is $\$ 8,900$. You scour the local newspapers and online listings. You have seen the car you want in a local lot for $\$ 11,000$, but you think that is quite high. You find one in "excellent condition" (per the seller's report) on eBay. Here is what you know about this seller:

- This seller has a positive feedback score of 96.9 percent, with 132 ratings.

- The seller has a 4.5 rating for "Communication" and "Shipping time" and a 4.3 rating for "Item as described."

- The seller sells a variety of used goods; this seller is not primarily a car dealer.

- The most recent 3 comments in the "Latest Feedback" screen for this seller are "Perfect. Thanks!!!"; "Good price with free shipping"; and "Solid B+ seller." 
The conditions provided:

\section{STUDY 2. LAST-MINUTE WARRANTY STUDY}

Contract

You can buy the car now for $\$ 8,700$. This price seems reasonable to you and you decide to purchase the car. You sign the basic agreement of sale, and arrange for delivery. When you have submitted your payment, you get an email from eBay about an eBay insurance product. eBay sells a warranty that you can purchase from them separately, up until the day before delivery of the product. The price varies depending on the product, but the idea is that eBay will warranty the product, guaranteeing you a full refund, no questions asked, if you are unhappy upon delivery. (The normal policy is that contested returns go through an eBay dispute resolution procedure.)

The seller has seemed reasonable so far, and you have submitted payment for the car, but you still have the choice to buy the warranty.
No Contract

You can buy the car now for $\$ 8,700$. This price seems reasonable to you. You start emailing with the seller to see if you can agree on the details and arrange a sale. While you are still working things out with the seller and the sale is not final, you are made aware of an eBay insurance product. eBay sells a warranty that you can purchase from them when you submit payment to the seller. The price varies depending on the product, but the idea is that eBay will warranty the product, guaranteeing you a full refund, no questions asked, if you are unhappy upon delivery. (The normal policy is that contested returns go through an eBay dispute resolution procedure.)

The seller seems reasonable so far, and you have already made up your mind to buy the car, but the sale is not final.

In both the Contract and the No Contract condition, buyers were then asked:

(1) What is the likelihood that you would purchase the eBay warranty if it were priced at $\$ 150$ ?

(2) What is the most you would pay for the eBay warranty at this point? (In dollars)

2. Results.

In this case, the hypothesis was that subjects would report more interest in the warranty, and a willingness to pay a higher price for it, in the No Contract condition. Both predictions were borne out by the data. Subjects in the Contract group reported a mean likelihood to purchase a warranty of 5.35 on a 7-point 
scale, compared to a mean of 5.67 in the No Contract group $(W=18504.5, p=0.030)$. As in Study 1, we also parsed this data by looking at the increased proportion of subjects reporting that they would either likely or very likely purchase the warranty. In this case, 34 percent of subjects in the Contract group and 44 percent of subjects in the No Contract group said they would very likely buy the warranty $(W=18839.5, p=0.033)$. A similar, though not significant, trend emerges by comparing whether subjects are likely (a rating of 5 to 7) to buy the warranty or not: 77 percent are likely in the Contract condition, and 82.5 percent are likely in the No Contract condition $(W=19838, p=0.162)$.

The willingness-to-pay question also differed significantly. Subjects in the Contract group were willing to pay $\$ 175.53$ on average for the warranty, but subjects in the No Contract group would pay, on average, $\$ 196.07$. This is also a statistically significant difference under one-tailed tests $(W=18885, p=0.015)$.

Overall, subjects found the warranty more attractive before they had finalized the deal than after, even reporting that they would pay more for it ex ante than ex post. In Study 1, a number of mechanisms were posited for why parties might be more willing to request a liquidated damages clause during negotiations rather than after. Here, many of those explanations are inapplicable because the main transaction is separate from the warranty purchase. The price of the warranty is not different across conditions, nor is it more or less of a hassle to purchase. And, since the warranty seller is not the car seller, the warranty can be purchased without any signals about the primary contract.

However, these results are plausibly subject to one additional alternative explanation that is particularly hard to eliminate in the contract context. The issue is this: subjects who read that they have signed the contract may believe that they only would have signed the contract if they were very confident about the other party's likelihood to perform. Although there is no content to the contract descriptions to support this inference, it tracks real-world experience. We trust people we are in contracts with more than those we aren't, believing we chose our contracts counterparties precisely because we found them trustworthy. Study 3 is designed to make the moment of contracting appear essentially arbitrary. 
C. Study 3

1. Method.

This study tested subjects' sensitivity to the isolated fact of being party to a contract on the decision to "shop around" for better terms. One of the goals of this study was to narrow the distinction between Contract and No Contract until it was no longer plausibly relevant to precautions decisions. Subjects in the Contract group read that their car purchase contract could be cancelled, with no penalty, within three days of purchase. Subjects in the No Contract group read that their contract had been signed but would not go into effect for three days, and they could opt out until then. This description was intended to make the notion of contract as meaningless as possible. Thus, in both cases, doing nothing leads to contract, and returning the car within three days of purchase cancels the contract and has no other legal repercussions.

Thirty female and thirty-one male incoming Temple University law students responded to a voluntary ten-minute questionnaire about contracts. They were not compensated. The subjects were randomly assigned to see all items in the Contract or No Contract condition. The scenario read as follows:

Please imagine that you are in the market to lease a new car, a Chevy Blazer. You find the car you want for the reasonable price of $\$ 300$ per month at Tim's Auto World. 
The conditions read:

\section{STUDY 3. FREe RETURN STUDY}

Contract

You go to the dealership and sign the standard lease contract, which includes a three-day return clause-if you don't want the car, you can return it, no questions asked, during the first three days. In other words, your lease is under contract, but you have three days to cancel with no legal or financial consequences. You take the car home.

Remember: You are under a contract, but you can walk away without consequence.

On your second day with the new car, you see an ad in the paper from Discount Car Universe: “Chevy Blazers Leased at Deep Discount!" with a number to call for more information.
No Contract

You go to the dealership and Tim tells you that you can take the car home and use it for three days. If you like it, you just keep it, and the standard contract goes into effect. In other words, your lease is not under contract, but the standard lease agreement will kick in in three days if you do not bring the car back. You take the car home.

Remember: You are not under contract.

On your second day with the new car, you see an ad in the paper from Discount Car Universe: "Chevy Blazers Leased at Deep Discount!" with a number to call for more information.

We included three dependent variables. Wording of the questions did not differ across conditions. Likelihood questions were answered on a Likert scale where 1 was "very unlikely," 4 was "neutral," and 7 was "very likely."

(1) What is the likelihood you would call Discount Car Universe?

(2) Now please imagine that newspaper ad lists the lease price for the same make and model of the car you have from Tim's. They are leasing the same new Chevy Blazer that you have for $\$ 265 /$ month. What is the likelihood that you would decide to return the car you have to Tim's and go with the Discount Car Universe option?

(3) Imagine that they have the same new Chevy Blazer. What is the highest monthly rate at which you would decide to return the car you have to Tim's and go with the Discount Car Universe option? 
2. Results.

Data from sixty total subjects was analyzed; twenty-nine in the Contract condition and thirty-one in the No Contract condition. One subject was omitted from the analysis for failure to follow instructions.

TABLE 1. RESULTS FROM FREE RETURN STUDY

\begin{tabular}{lll} 
& Contract & No Contract \\
\hline \hline Call to learn discount & 5.34 & 6.03 \\
Return for $\$ 35$ savings & $5.52^{*}$ & $6.13^{*}$ \\
Price to switch dealers & $\$ 267.69^{*}$ & $\$ 284.45^{*}$ \\
${ }^{*} p<0.05$ & &
\end{tabular}

The Call variable is not significant by itself $(W=385.5$, $p=0.323)$, but both Return $(W=290.5, p=0.014)$ and Price $(W=282.5, p=0.013)$ differ significantly across conditions. The Call and Return variables were also combined to test the overall willingness to shop around. The total shop around "score" is significantly different between groups $(W=310.5, p=0.0368)$.

These results suggest that the Contract/No Contract effect persists even when the Contract/No Contract distinction is unrelated to selection. We discuss the implications of this series of experiments below.

\section{IMPLICATIONS FOR THE PSYCHOLOGY OF CONTRACT}

Taken together, these studies provide evidence that across a range of precaution types, people report that they would be less willing to protect their interests vis-à-vis a contractual counterparty once in a contract. They are less willing to include a liquidated damages clause, less willing to purchase a warranty, and less willing to investigate other options when they are already party to the contract, even when the formalization of the contract is essentially arbitrary and without legal consequence.

In this Part, we explore several psychological mechanisms that plausibly explain these results. We divide these explanations into two groupings. The first is a prospect theory explanation, which posits that the moment of contracting establishes a reference point that frames how parties value the costs and 
benefits of self-protective behavior..$^{70} \mathrm{~A}$ prospect theory explanation focuses on the different mental accounting parties engage in when deciding whether to increase the contract price by adding the cost of a precaution or to incur a separate loss by purchasing a precaution after the contract has been signed.

The second explanation is less straightforward. We draw on existing cognitive and behavioral psychology research to argue that the mere fact of being contractually bound affects parties' attitudes toward one another. They are wary and adversarial in the precontract vetting. Once they have entered the contract, they are trusting and cooperative-even when the moment of formation is essentially meaningless. People may follow this algorithm because it is a good rule of thumb. They may also be particularly trusting in contracts because they are motivated to trust, as it does not feel good to be contractually bound to an untrustworthy counterparty.

We note at the outset that the three studies reported above cannot distinguish between the explanations we are positing here. The following sections consider both explanations and discuss them in light of current controversies in contract doctrine and policy.

\section{A. Prospect Theory}

The idea of contracts as reference points is substantially motivated by the tenets of prospect theory, the overarching theory of experienced utility that explains phenomena like the status quo bias and the endowment effect. Prospect theory says that people evaluate outcomes by comparing them to a reference point: They weigh losses more heavily than gains, and they are risk averse in the domain of gains but risk seeking in the domain of losses. ${ }^{71}$ The reference point is the kink in the value function, the state of the world to which any outcome is compared. Prospect theory suggests that people code the cost of vigilance in its various forms (shopping around, buying warranties, and so forth) around reference points. 72 This has several effects on how people may judge the value of precautions based on how

70 See Hart and Moore, 123 Q J Econ at 12 (cited in note 8).

71 See Chris Guthrie, Prospect Theory, Risk Preference, and the Law, 97 Nw U L Rev 1115, 1118 (2003).

72 See id (explaining that people "evaluate decision options" in relation to a reference point that represents the "status quo"). 
they understand the status quo and how they mentally bundle the costs and benefits of self-protection. ${ }^{73}$

\section{Mental accounting.}

Because the marginal utility of gains is declining, and the marginal disutility of losses is declining, ${ }^{74}$ people have preferences for how to account for multiple gains and losses. In short, utility is maximized when gains are segregated (lots of small gains are better than one big gain) and losses are integrated (one big loss is better than lots of small losses). ${ }^{75}$ In this same vein, and also relevant to our results, when people have a "mixed gain"-which is to say, a mixture of gains and losses that results in a net gain-they prefer integration to segregation. ${ }^{76}$ This is a fairly simple explanation for why we might see people opting to add a warranty into the contract price when they would never be willing to pay for the warranty if they were contacted about it two days after the initial product purchase. In the precontract case, purchasing the precaution means raising the contract price. In Study 2, subjects willing to pay $\$ 150$ for the warranty precontract might think that they are going from a loss of $\$ 8,700$ to $\$ 8,850$. Once the contract is signed, the reference point is reset, and the warranty means moving from a cost of $\$ 0$ to a cost of $\$ 150$. The analysis holds up if we think of the contract as a mixed gain. ${ }^{77}$ Because losses loom larger than gains, a smaller gain is preferable to a bigger gain plus a separate loss.

73 See id at 1115, 1118-19 (suggesting that prospect theory allows theorists to understand how people evaluate whether or not to take precautions based on perceived consequences); Cass R. Sunstein, Terrorism and Probability Neglect, 26 J Risk \& Uncertainty 121, 123 (2003).

74 See Alan Schwartz, Julie Goldberg, and Gordon Hazen, Prospect Theory, Reference Points, and Health Decisions, 3 Judgment \& Dec Making 174, 176 figure 1 (2008) (depicting the prospect theory value function).

75 See Richard Thaler, Mental Accounting and Consumer Choice, 4 Mtkg Sci 199, 201-02 (1985).

76 See id.

77 In terms of utility, contracts are almost certainly mixed gains because people are typically getting something that they want more than they want the money. See David D. Friedman, Law's Order: What Economics Has to Do with Law and Why It Matters 1819 (Princeton 2000) (explaining that based on rational-choice theory, economic legal analysis understands the way a contracting party values a given exchange based on her willingness to enter into the transaction). However, the mixed-gain analysis is not necessarily a perfect fit here because people may not think of their own benefit in monetary terms. See, for example, Robert D. Rowe and Lauraine G. Chestnut, The Value of Visibility: Economic Theory and Applications for Air Pollution Control 10, 80-81 (Abt 1982). 


\section{Status quo bias.}

The status quo bias describes an individual's preference for the current state of the world, even in the face of evidence that a particular change has a high probability of yielding net benefits. ${ }^{78}$ The status quo bias is related to the endowment effect: people who are endowed with a good value it more highly than those who are not endowed with it, even when the initial endowment is randomly assigned.79 Because potential losses loom larger than potential gains, those faced with the possibility of making a switch underestimate the utility of new benefits and overestimate the disutility of losing currently valued attributes. ${ }^{80}$

Favoring the status quo is often quite rational. ${ }^{81}$ Sometimes the status quo has been well researched and carefully chosen, invested in over time, and thoroughly vetted. It deserves to be favored. But the status quo bias research says that people favor the status quo even when none of the above apply.82 Even if experimenters just randomly assign one option as the status quo, and inform participants that the "status quo" designation is random, participants are still more reluctant to make a different choice. 83 Switching feels different than choosing. This is the prospect theory explanation for the results of Study 3. The status quo in the No Contract condition is just that-no contract, no car lease. Switching when that is the case is more attractive than when the car is under lease, even when cancellation is permitted.

In all, the implications of prospect theory for precautions are fairly straightforward. Individuals deem the precaution less

78 See Russell Korobkin, The Endowment Effect and Legal Analysis, $97 \mathrm{Nw}$ U L Rev 1227, 1228-29 (2003) (defining the "status quo bias").

79 See id (explaining that the status quo bias leads to the "offer-asking gap," in which people require a higher price to sell a good than they would offer to purchase the same good).

80 For classic demonstrations of how the status quo bias may in general motivate contracting parties to prefer preexisting form terms, see Russell Korobkin, Inertia and Preference in Contract Negotiation: The Psychological Power of Default Rules and Form Terms, 51 Vand L Rev 1583, 1605-07 (1998); Russell Korobkin, The Status Quo Bias and Contract Default Rules, 83 Cornell L Rev 608, 633-66 (1998).

81 See Korobkin, $97 \mathrm{Nw}$ U L Rev at 1280 (cited in note 78) ("[T]he endowment effect is not obviously 'irrational' behavior: a preference for what one has over what one does not have, or for what one is accustomed to compared to the unknown, is no more troublesome than a preference for chocolate ice cream over vanilla."); William Samuelson and Richard Zeckhauser, Status Quo Bias in Decision Making, 1 J Risk \& Uncertainty 7, 3335 (1988).

82 See Korobkin, 83 Cornell L Rev at 624 (cited in note 80) (explaining that rational choice theory cannot account for the status quo bias).

83 See id at 626. 
valuable, or more costly, if they have already signed the contract. This has consequences for some real-world contracts dilemmas. For example, in the insurance context, a number of commentators have expressed surprise that people are willing to purchase extended warranties for consumer goods, goods that almost no one would insure under any other circumstances. ${ }^{84} \mathrm{At}$ least in part, there is a mental accounting explanation for this. Before the purchase is final, when the sales clerk offers the warranty, the protection is rolled into the contract price. Once the item is purchased, though, any additional insurance is an extra loss. Similarly, consumers often find themselves renewing contracts that they would never choose, all else being equal-they are biased toward the status quo.

Prospect theory is a plausible explanation for our findings that parties take a different attitude toward precautions before and after finalizing a contract, assuming that the subjective experience of formation is the relevant reference transaction. First, when a costly precaution is included in the total contract price, the loss is coded as less severe than it is when the loss is a separate hit that comes after the contract price because of the declining marginal disutility of losses. Second, sometimes the wise precaution for a party to take is to seek a different counterparty. The status quo bias predicts that people will be reluctant to do so if they consider the current contract a done deal.

\section{B. Relational Contracting and Overtrust}

Our alternate (and possibly complementary) explanation for the differential approaches to precautions before and after contracting is that people take a different stance, both interpersonally and cognitively, toward a potential counterparty who is being vetted than toward a contract partner. Negotiating is adversarial, but performing is cooperative. There are two possible reasons for this, the first of which is deliberate and rational and the second of which is implicit and intuitive.

Of course parties may reasonably believe that once the contract is signed, trusting is simply more efficient. Even commercial actors sometimes prefer to structure their business agreements

84 See, for example, Tao Chen, Ajay Kalra, and Baohong Sun, Why Do Consumers Buy Extended Service Contracts?, 36 J Consumer Rsrch 611, 611 (2009) ("Although most consumer magazines and experts advocate consumers not buy [extended service contracts] because they provide little value, it is intriguing that the demand for [extended service contracts] remains high."). 
informally, with an implicit or explicit reliance on personal moral commitments and community norms rather than formal legal sanctions. Professor Stewart Macaulay brought this to light in his analysis of real-world contracting between Wisconsin businessmen in the 1960s, noting that many of them exchanged formal written contracts but ignored them. ${ }^{85}$ Professor David Charny followed up on this research with a systematic analysis of the benefits of nonlegal sanctions. Professor Charny argued that in many cases, commercial actors may be rational to depend on social and psychic harms to deter promise breaking. ${ }^{86}$ And, as described in Part II, people may realize that there are social norms around interpersonal trust in contract that are not worth violating because the violation of such norms will hinder the relationship, inducing shirking or retaliation on the part of the counterparty. ${ }^{87}$ Which is all to say that sometimes parties intentionally ground their mutual obligations in promissory morality. This explanation is entirely sensible and quite relevant to many contracts relationships, but it is one that we will set to the side at this point. ${ }^{88}$ People may have rational preferences for trusting their counterparties in some cases, but we think in many cases this is neither a robust preference nor a helpful stance. You might want to let down your guard with your credit card company, but it is probably unwise to do so.

Rather, the norm of interpersonal trust in contracts may operate in some cases as a rule of thumb. The rule works very well for interpersonal promises, works pretty well for long-term negotiated agreements (employment, for example), and works quite poorly for contracts of adhesion between consumers and firms. The idea of a rule of thumb for interpersonal trust in contract is related to existing research on the commonsense approach to contract and promise. This research argues that people use the idea of promise in a kind of heuristic sense, assuming that their legal obligation tracks their understanding of the moral

85 Stewart Macaulay, Non-contractual Relations in Business: A Preliminary Study, 28 Am Soc Rev 55, 58-60 (1963).

86 David Charny, Nonlegal Sanctions in Commercial Relationships, 104 Harv L Rev 373, 391-425 (1990).

87 See notes 50-53 and accompanying text.

88 For a more in-depth look at promissory morality, see Claire A. Hill and Erin Ann O'Hara, A Cognitive Theory of Trust, 84 Wash U L Rev 1717, 1755-56 (2006) (discussing contract law's role in promoting optimal trust). 
obligation entailed in promise. ${ }^{89}$ People assume that specific performance is a typical remedy, believe that willful breachers should be punished more harshly than unfortunate breachers, and experience the harm of breach as a harm of betrayal-in other words, they evaluate breach of contract along the same dimensions as promise breaking. ${ }^{90}$ Our intuition is that for those who reflexively think about contracts in terms of ordinary promissory morality, the fact of being in a contractual relationship comes with an assumption that interpersonal trust is the appropriate norm.

It is also possible that people are not just mindlessly adhering to a trust-in-contract heuristic but that they are motivated to be trusting because they would feel so foolish for having chosen an untrustworthy counterparty. People may not want to check up on a current contract partner because doing so may reveal that the initial assessment or choice of counterparty was flawed. Cognitive dissonance is a psychological phenomenon that describes this tendency to reconcile discrepancies between beliefs and past choices by adjusting the beliefs. ${ }^{91}$ People make many decisions for reasons that are not in line with their beliefs. In the contracts context, we might sign a credit card contract because the salesperson is particularly charming or aggressive, or we might reorder a low-value good (say, a newspaper subscription) because we forget to opt out. These are not particularly compelling reasons for contracts and may cause some amount of cognitive tension as the consumers hold two dissonant beliefs. For example, I do not like this credit card company; I am contractually bound to this credit card company. Cognitive dissonance theory says that people will often reduce that tension by changing the belief (this contract is desirable), since the action is already past. ${ }^{92}$

89 See Jody S. Kraus, The Correspondence of Contract and Promise, 109 Colum L Rev 1603, 1635 (2009). See generally Kevin M. Teeven, Origins and Scope of the American Moral Obligation Principle, 46 Cleve St L Rev 585 (1998).

90 See Tess Wilkinson-Ryan and Jonathan Baron, Moral Judgment and Moral Heuristics in Breach of Contract, $6 \mathrm{~J}$ Empirical Legal Stud 405, 420-23 (2009).

91 See Leon Festinger, A Theory of Cognitive Dissonance 18-31 (Stanford 1957).

92 See Yuval Feldman and Doron Teichman, Are All Contractual Obligations Created Equal?, 100 Georgetown L J 5, 26-27 (2011) (hypothesizing that "the process of contracting, so long as it is the outcome of free choice, could lead to a deeper commitment to the contracts' terms"); Stephanie Stern, Temporal Dynamics of Disclosure: The Example of Residential Real Estate Conveyancing, 2005 Utah L Rev 57, 86 (arguing that late disclosures in real estate contracts will be ignored because buyers are invested in the deal going forward); Shmuel I. Becher, Behavioral Science and Consumer Standard Form 
People who have opted into a relationship or a purchase will avoid or misremember information that suggests they made the wrong choice. For example, people who have just bought a new car are more likely to notice advertisements whose content supports their purchase decision.93 Even more interesting from our perspective is a study of mutual fund investors. Mutual fund investment by nonprofessionals is characterized by a high level of inertia; investors stay with poorly performing funds even when there is no economic justification for doing so. ${ }^{94}$ This means that many investors are faced with the kind of dissonance we have described above: I have chosen to stick with this fund for many years when I could have chosen to sell it; this fund has done poorly for many years. ${ }^{95}$ Nadav Peles and Professor William Goetzmann sent mutual fund investors a questionnaire about the mutual funds they used and how the funds had performed in the past. ${ }^{96}$ Respondents explicitly reported that they would not continue to hold a poorly performing fund for a long time. ${ }^{97}$ They did not hold a belief that justified their decisions to hold what the authors described as "an unusually high frequency of poorly performing funds." 98 However, investors drastically overestimated the returns of funds they had chosen themselves. ${ }^{99}$ They selectively remembered data points that affirmed their choices.

Cognitive dissonance theory predicts that people engage in a selective search for information. This is similar to the theory of confirmation bias, which suggests that people who are trying to evaluate a hypothesis are more likely to look for information that supports the hypothesis than to search for potentially falsifying evidence. ${ }^{100}$ People do not look for information that will disconfirm a belief (for example, I have signed on with the right counterparty), and in fact they do not want such information. This may explain the choice not to monitor and not to shop

Contracts, 68 La L $\operatorname{Rev} 117,131-32$ (2007) (arguing that individuals are less likely to take care with terms after they have decided to enter a contract).

93 See Danuta Ehrlich, et al, Postdecision Exposure to Relevant Information, $54 \mathrm{~J}$ Abnormal \& Soc Psych 98, 101 (1957).

94 See William N. Goetzmann and Nadav Peles, Cognitive Dissonance and Mutual

Fund Investors, $20 \mathrm{~J}$ Fin Rsrch 145, 152-53 (1997).

95 Id at $146-47$.

96 Id at $147-60$.

97 Id at $148-49$.

98 Goetzmann and Peles, $20 \mathrm{~J}$ Fin Rerch at 145, 150-52 (cited in note 94).

99 See id at $148-49$.

100 See Raymond S. Nickerson, Confirmation Bias: A Ubiquitous Phenomenon in Many Guises, 2 Rev Gen Peych 175, 177-78 (1998). 
around. And, of course, the choice to purchase a precaution may itself be a source of tension. It means holding two dissonant beliefs-I have already chosen this partner; I do not trust this partner.

\section{Next Steps in the Psychology of Precautions}

We have begun to sketch a picture of the kink in decision making at the moment of contracting, and we have reviewed literature that may help explain the phenomenon. However, this Article cannot distinguish between the explanations we have offered (prospect theory and overtrust), nor can we rule out other explanations. This is a real problem for understanding which contexts are most relevant to our findings. Prospect theory is a powerful foundation for precautions that require extra payment, or where there is a status quo bias at issue, but the overtrust explanation seems more compelling as an explanation for why consumers do not read late-arriving riders to their contracts. Identifying the psychological mechanism, or mechanisms, that explain our results is the next step in this research.

Our argument also elides the important observation that people feel differently about different kinds of contracts. ${ }^{101}$ Our psychological response to contracts of adhesion is and should be different than the psychology of long-term deals with well-liked business partners. Recent research suggests that people are held responsible for the moral commitment of contract in ways that corporations are not. ${ }^{102}$ And form contracts may be perceived as generally less fair and less enforceable than other contracts. ${ }^{103}$ Even without empirical support, it seems reasonable to predict that consumers signing form contracts with large companies will

101 We recognize that precautionary behavior is likely to be different depending on the kind of contract that parties are in. This Article is about the broad class of contracts that individual nonmerchants might be party to, including negotiated agreements like home renovation contracts and consumer contracts of adhesion like cell phone contracts. We intentionally exclude employment contracts, although doctrinal questions surrounding formation of such contracts and compliance with their terms abound in that area of law. That is, we argue that individuals generally behave differently whether or not the contract has begun, but we realize that the effect of contract may be moderated by the kind of contract.

102 See, for example, Uriel Haran, A Person-Organization Discontinuity in Contract Perception: Why Organizations Can Get Away with Breaking Contracts but Individuals Cannot *23 (unpublished manuscript, 2012), online at http://aw.huji.ac.il/upload/ HaranContractBreach.pdf (visited Mar 3, 2013).

103 See, for example, Zev J. Eigen, The Devil in the Details: The Interrelationship among Citizenship, Rule of Law, and Form-Adhesive Contracts, 41 Conn L Rev 1, 18-19 (2008). 
show a smaller effect of contract than those in agreements with other individuals. We predict that this is a moderator of the effect we have demonstrated, and we hope to test this prediction empirically in future work.

Finally, one of the most interesting questions raised but not addressed in this research is the question of when people think they are in contracts. In the studies reported above, subjects were told in plain language that a contract period had or had not begun. We speculate, though, that the moment of contracting may be subject to manipulation. ${ }^{104}$ Even when a court would find that the contract was not finalized, for example, consumers who have signed their name to something, or executed the primary exchange, may understand themselves to be in a contract. ${ }^{105}$ In fact, we might even worry that a salesperson may push for an oral agreement and then present the written contract as an apparent afterthought. This is precisely the scenario that makes policy makers especially nervous in contexts like subprime mortgage lending. ${ }^{106}$ One of the contributions of psychological research may be to pin down the factors that lead consumers to consider a deal finalized.

\section{Discussion}

Given the basic phenomenon that emerges from the studies here, there are some initial points to make about the doctrinal implications of our findings. That the moment of contracting is special isn't exactly earth-shattering. Indeed, the first-year contracts class is built around the instant when two minds meet and agree to do business with one another. Our experiments suggest, however, that this moment produces a behavioral kink, divorced from concerns about cost, or projection of future legal

104 Consider Robert A. Hillman and Jeffrey J. Rachlinski, Standard-Form Contracting in the Electronic Age, 77 NYU L Rev 429, 480-82 (2002) (discussing ways in which firms could encourage consumers to fail to read their contracts online).

105 See Anthony M. Balloon, From Wax Seals to Hypertext: Electronic Signatures, Contract Formation, and a New Model for Consumer Protection in Internet Transactions, 50 Emory L J 905, 934 (2001) ("That a signature is the central formality in contract formation-particularly in a consumer transaction-cannot be overstated. Most consumers equate their signature with being bound to the terms of an agreement.").

106 See Kathleen C. Engel and Patricia A. McCoy, Turning a Blind Eye: Wall Street Finance of Predatory Lending, 75 Fordham L Rev 2039, 2043-45, 2080 (2007) (including in its definition of predatory lending nonfraudulent forms of nontransparency between brokers or lenders and consumers). 
remedies. What is the practical upshot of the research that we have undertaken?

\section{A. Reimagining Precautions}

This Article seeks to expand the category of precautions to include self-interested or self-protective behavior more generally. In our view, the literature on "precautions" focuses too narrowly on those precautions that parties may take after they have entered into the contract and which protect against breach. But there are many steps that ordinary consumers can take to protect themselves, not simply against breach of their contracts, but from exploitative or undesirable behavior by their counterparty. Such behaviors, which maximize gains from the contracting relationship, are precautionary, and we posit that they will be subject to a similar psychic calculus as the precautions against breach that our experiments directly targeted.

For example, reading a contract carefully is a precaution. ${ }^{107}$ Hidden terms are not always unenforceable, even if the promisee and court agree that they are unfairly surprising. But when a credit card company exploits a hidden term in the contract to raise a cardholder's interest rates, or deny class certification, it harms the cardholder in ways that the cardholder did not intend to be vulnerable to. Another example of a common precaution is hiring a lawyer. Ordinary people involved in higher-stakes deals (home purchases, for example) take this precaution-not only to protect against the possibility that the seller will breach but also to ensure that the contract itself protects the buyer's interests. ${ }^{108}$ And, of course, one of the most important ways that consumers protect themselves is by shopping around. Comparing terms and prices and selecting good deals are the primary means by which consumers can influence the terms of form contracts. ${ }^{109}$

107 This is not, of course, a new insight. See, for example, Erin Ann O'Hara, Choice of Law for Internet Transactions: The Uneasy Case for Online Consumer Protection, 153 U Pa L Rev 1883, 1925 (2005) (exploring social and psychological forces that reduce the likelihood that consumers will protect themselves by reading their agreements).

108 See Michael Braunstein and Hazel Genn, Odd Man Out: Preliminary Findings Concerning the Diminishing Role of Lawyers in the Home-Buying Process, 52 Ohio St L J 469,471 (1991) (citing a survey in which the most commonly articulated reason for home buyers hiring a lawyer was for the lawyer to "protect" the buyer).

109 But see Florencia Marotta-Wurgler, Competition and the Quality of Standard Form Contracts: The Case of Software License Agreements, $5 \mathrm{~J}$ Empirical Legal Stud 447, 473-74 (2008). 
Construed broadly, precautions matter for ordinary consumers, and this has implications for analysis of precautions. First of all, it means that the scope of the issue is big: it involves almost all contracts, not just negotiated agreements between sophisticated players. Second, it means that economic analyses are less likely to accurately predict precautionary behavior because ordinary citizens are more likely than commercial or institutional actors to deviate from the rational actor model in noticeable, systematic ways. This approach to defining contractual selfprotection motivates the focus here. We ask when ordinary promisees-for example, consumers-protect themselves against deficient performance, and how cognitive biases may discourage optimal precaution taking even when economic analysis suggests that they ought to protect themselves.

So reimagined, the nexus of precautions (against breach and exploitation) and psychic costs (both prospect theory and overtrust) has certain potential doctrinal implications. We must be quick to emphasize the tentativeness of our conclusions. Not only is our work subject to the ordinary caveats about survey research, which we explore at length below, but we would need to directly test whether in fact individuals' vigilance against breach and exploitation is similarly kinked. If it is, and we think there is no obvious theoretical reason that it would not be, we would further want to understand how different kinds of contracts and contracting parties moderate the effects we have seen. Still, there is a possibility that understanding contractual vigilance as a reference point problem will have certain transformative implications, which we now describe.

\section{B. Easy Cases: Good Faith and Modification}

In some areas of doctrine, we think that reemphasizing the moment of contracting fits well with the current approach of courts and scholars. For example, consider the doctrine of good faith. Loosely defined, opportunism is selfishness and denial of the implicit duty one owes another to behave in ways that are socially acceptable. As Professor Erin O'Hara O'Connor observes, the anti-opportunism good faith doctrine applies to parties in a contracting relationship but not to counterparties with whom deals are not yet concluded:

[C]ontracting parties are entitled to behave in a complete selfinterested fashion when they are choosing contracting partners and negotiating contract terms. Once the relationship 
has been formed, however, the parties are expected to treat the contract as a kind of partnership-the relationship is supposed to benefit both parties, and performance or termination which deprives one of the parties of the substantial value of the contract is simply unacceptable. ${ }^{110}$

Good faith thus acts as a powerful check against the impulse to take advantage of a counterparty. It punishes actions which are antisocial, denies unreasonable or harmful exercises of contractual rights, and prohibits "game playing" with respect to contracting terms. ${ }^{111}$ But before the moment of contracting, we are free to behave in exactly such socially outrageous ways.

Indeed, checks on exploitative behavior precontract are weak. Though parties may not lie about facts, they may (generally) puff. ${ }^{112}$ Though sellers may not exercise undue influence, that defense is famously almost impossible to prove at trial.113 Duress prevents the most extreme examples of negotiation pressure, but the far more common situation of a party benefiting from another's economic necessity is generally perfectly legal.114 Overall, parties failing to take precautions against exploitative behavior precontract are unlikely to be protected by the law, while parties in a contract who are similarly trusting are entitled to a measure of legally funded insurance. In this way, the law generally tracks our experimental findings about how laypeople perceive the importance of the moment of contracting.

By contrast, the modern approach to modification appears to badly match the behavioral effects we have shown. Historically, the common law generally viewed modifications to contracts

110 Erin Ann O'Hara, Trustworthiness and Contract, in Paul J. Zak, ed, Moral Markets: The Critical Role of Values in the Economy 173, 187 (Princeton 2008). See also Restatement (Second) of Contracts $\$ 205$, comment c. That said, there are of course strands of good faith doctrine written into the negotiation process. For example, courts will routinely "fix" illusory contracts by implying some reasonable set of reciprocal obligations into the parties' terms. See, for example, Wood v Lucy, Lady Duff-Gordon, 118 NE 214, 214-15 (NY 1917); Palisades Properties, Inc v Brunetti, 207 A2d 522, 531 (NJ 1965).

111 See Joseph M. Perillo, Calamari and Perillo on Contracts $\$ 11.39$ at 417 (West 6th ed 2009).

112 See David A. Hoffman, The Best Puffery Article Ever, 91 Iowa L Rev 1395, 142027 (2006).

113 See Kellye Y. Testy, An Ode to Odorizzi, excerpted in Randy E. Barnett, Contracts: Cases and Doctrine 1018, 1019 (Aspen 4th ed 2008); Jon Hanson and David Yosifon, The Situational Character: A Critical Realist Perspective on the Human Animal, 93 Georgetown L J 1, 14 (2004) (describing undue influence and duress as "very narrow doctrines").

114 Perillo, Contracts $\S 9.7$ at 284 (cited in note 111) (discussing business compulsion). 
with suspicion. ${ }^{115}$ Such changes generally required new consideration (however slight). ${ }^{116}$ Where unforeseen circumstances made performance of the existing agreement unusually difficult, modifications which were fair and equitable could be enforceable. ${ }^{117}$ But such circumstances rested on an increase in the promisor's cost, not the availability of a benefit previously unanticipated. ${ }^{118}$ This treatment of modification made some sense from a psychological perspective. By focusing only on the increase in the promisor's cost, as opposed to opportunity costs, the rule operates asymmetrically, punishing breaches to gain, and permitting breaches resulting from losses. ${ }^{119}$ This fits well with previous research suggesting that individuals feel quite differently about these two scenarios. ${ }^{120}$

But, as we discussed in the Introduction, courts seem to be increasingly unwilling to police modifications to consumer agreements. ${ }^{121}$ Commentators bemoan the practice of imposing unilateral changes to common consumer contracts without providing any corresponding benefit. ${ }^{222}$ Such unilateral modifications are increasingly checked through viral campaignsconsider Verizon's proposed $\$ 2$ convenience fee for online credit card payment ${ }^{123}$ or Bank of America's $\$ 5$ fee for debit card

115 See, for example, United States v Stump Home Specialties Manufacturing, Inc, 905 F2d 1117, 1122 (7th Cir 1990) (arguing that modifications ought not be policed by good faith or consideration doctrines but rather unconscionability or duress); Levine $v$ Blumenthal, 186 A 457, 458 (NJ 1936).

116 The UCC disposes of the need for new consideration under $\$ 2-209(1)$, though of course the Code's general requirement of good faith prevails.

117 See Perillo, Contracts $\S 4.9$ at 164 (cited in note 111); Restatement (Second) of Contracts $\S 89$ (a).

118 See Brian Construction and Development Co v Brighenti, 405 A2d 72, 76 (Conn 1978) (holding a contract modification binding where one party would have been forced to incur unforeseen expenses under the initial contract).

119 See Aditi Bagchi, Managing Moral Risk: The Case of Contract, 111 Colum L Rev 1878, 1924 n 148 (2011).

120 See, for example, Wilkinson-Ryan and Baron, $6 \mathrm{~J}$ Empirical Legal Stud at 42023 (cited in note 90).

121 See Horton, 57 UCLA L Rev at 623-36 (cited in note 11); Bar-Gill and Davis, 84 S Cal L Rev at 8-16 (cited in note 12) (providing evidence of the scope of the unilateral modification problem).

122 See, for example, Catherine J.K. Sandoval, Disclosure, Deception, and DeepPacket Inspection: The Role of the Federal Trade Commission Act's Deceptive Conduct Prohibitions in the Net Neutrality Debate, 78 Fordham L Rev 641, 692-93 (2009) (explaining that many jurisdictions do not permit unilateral contract modification in the absence of additional consideration); Bar-Gill and Davis, 84 S Cal L Rev at 19-26 (cited in note 12).

123 Ron Lieber, After Outcry, Verizon Abandons $\$ 2$ Fee, NY Times B1 (Dec 31, 2011). 
use. ${ }^{224}$ Both modifications were ultimately abandoned after substantial public pressure, not a court's decision. ${ }^{125}$

The real question is what is wrong with unilateral modifications to a long-term consumer contract. One possibility is that such modifications are an expression of inequality in bargaining power, imposed through adhesive contracts without the possibility of change. Without disagreeing with that premise, one might fairly question why modified terms ought to be treated differently from those originally proposed in the deal. If we are to permit consumers to enter into adhesion contracts with large firms with little substantive regulation, why not similarly permit them to continue such relationships as modified over time?

Our experiments suggest that, internal to the contracting relationship, promisees are unlikely to perceive new terms in the same adversarial light as they might have before the contract was formed. This is particularly relevant to more complex or less salient terms like arbitration clauses. We would predict that in the contract, parties are less likely to read them, and having read them, probably less likely to perceive the likelihood of opportunistic behavior by their counterparties.

The precise mechanism for this effect remains unknown. Some have argued that status quo bias seems to provide a sufficient reason standing alone for parties to stand pat despite onerous proposed modifications. ${ }^{226}$ But we tend to think that motivated cognition and overtrusting provides a more powerful explanation. ${ }^{127}$ Because, as Professors Alces and Greenfield argue, contracts encourage relational investments, ${ }^{128}$ consumers may be caught flat-footed by their counterparties' attempts to change the terms of the deal. In either event, we agree with

124 Tara Siegel Bernard, Bank of America Drops Plan for Debit Card Fee, NY Times A1 (Nov 2, 2011).

125 See Lieber, Verizon Abandons $\$ 2$ Fee, NY Times at B1 (cited in note 123) (describing the online petition that caused Verizon to revoke the proposed policy); Bernard, Bank of America Drops Plan for Debit Card Fee, NY Times at A1 (cited in note 124) (noting dissatisfied customers' responses to the proposal).

126 See, for example, Eric A. Zacks, Unstacking the Deck? Contract Manipulation and Credit Card Accountability, 78 U Cin L Rev 1471, 1475 (2010); Russell Korobkin, Behavioral Economics, Contract Formation, and Contract Law, in Cass R. Sunstein, ed, Behavioral Law and Economics 116, 117-20 (Cambridge 2000).

127 Of course, these are not actually competing explanations. See, for example, Becher, $68 \mathrm{La} \mathrm{L}$ Rev at 138-40 (cited in note 92).

128 Alces and Greenfield, $26 \mathrm{Ga}$ St U L Rev at 1100 (cited in note 13). 
those commentators who suggest that courts should generally treat modifications with heightened scrutiny. ${ }^{129}$

And yet, this general conclusion requires an important caveat. If a modification is requested by an individual and is the subject of actual negotiation, current doctrine's emphasis on a requirement of changed circumstances seems overprotective. After all, our research suggests that inside of the relationship, precaution taking will be relatively rare. Modified bargains initiated by laypeople should be understood by the law to be the result of a special effort by one of the parties to recognize a breakdown in the relationship and an attempt to assert it on sounder footing. Even if such a new relationship results from the increase in the opportunity cost of performance, an individual's request for a modification of an executory bargain should be permitted if it comports with the general obligation of good faith. That is, we think that the UCC's approach to modification ${ }^{130}$ can be a better fit with folk psychology than the common law's preexisting duty rule.

\section{Harder Cases: Disclosure and Promissory Estoppel}

\section{Which terms are in the deal?}

In modification cases, and indeed in the experiments that we present in this Article, the moment of contracting is not in question. Parties either have or have not signed on the dotted line, and that distinction affects their behavior. However, in at least some cases, the deal proceeds in multiple phases, and the moment that the law recognizes a meeting of the minds is not the same as the moment that a consumer believes that the contract has begun. For example, a seller offers to sell a computer, and a consumer buys it over the phone. When the consumer opens the box at home, she finds onerous terms in a contract included in the packaging. Will a court later include such terms in the parties' agreement? Hill v Gateway 2000, Inc ${ }^{131}$ permitted such "rolling contracts," reasoning that the buyer surely knows

129 See, for example, Charles L. Knapp, Opting Out or Copping Out? An Argument for Strict Scrutiny of Individual Contracts, 40 Loyola LA L Rev 95, 126-35 (2006) (arguing for more rigorous judicial standards in evaluating "rolling contracts").

130 See UCC § 2-209(1) (ALI 1962).

131105 F3d 1147 (7th Cir 1997). 
more terms are coming and can cancel the contract by returning the computer. ${ }^{132}$

Hill implicates both prospect theory and trust explanations for the consumers' apparently unwary behavior. Because the contract had already been "signed" by both parties, ${ }^{133}$ returning the product meant a shift from the status quo-switching rather than choosing. And, because the contract period had begun, consumers who trusted the counterparty would be less likely to take the simplest precaution of reading the terms.

Hill has been immensely controversial. It famously misapplied the UCC, which would have likely thrown out the latearriving terms. ${ }^{134}$ But in discounting the value of precontract disclosure, it sparked a debate that continues to the present day. ${ }^{135}$ That debate is essentially about when promisees can be charged with failing to protect themselves against bad terms. On the one side are the drafters of the American Law Institute's new Principles of the Law of Software Contracts. ${ }^{136}$ Professors Robert Hillman and Maureen O'Rourke, reporters of the Principles, defended mandatory disclosure before contracting against its many critics. Although acknowledging that mandatory disclosure of terms can create costs and that terms are unlikely to be read by contracting parties, they argue that disclosure is necessary to preserve the legitimacy of the state-run contract enforcement regime:

Standard forms constitute private legislation backed by the state's enforcement processes, and the legitimacy of these forms also depends on reasonable notice of content. In fact, adequate notice of terms constitutes a foundation for much of contract doctrine, including rules of interpretation (such

132 Id at 1150. See also ProCD, Inc v Zeidenberg, 86 F3d 1447, 1451-53 (7th Cir 1996).

133 In reality, the Hills agreed to a sale on the phone. See Hill, 105 F3d at 1148.

134 See Klocek v Gateway, Inc, 104 F Supp 2d 1332, 1339 (D Kan 2000) (stating that UCC $\$ 2-207$, which governs the inclusion of additional terms in acceptance or confirmation of a contract, applies even when there is only one written form); Perillo, Contracts $\$ 2.12$ at 64 (cited in note 111) (describing the reasoning in Hill as flawed because according to the UCC the terms in the box constituted additional terms that do not become part of a contract).

135 For a summary of this debate, see generally Robert A. Hillman, Rolling Contracts, 71 Fordham L Rev 743 (2002).

136 ALI, Principles of the Law: Software Contracts $\$ 2.02 \&$ comments $--h(2009)$; Hillman and O'Rourke, $78 \mathrm{U}$ Chi L Rev at 106-08 (cited in note 17). 
as interpreting terms against the drafter), the parol evidence rule, and, of course, the general rules of formation. ${ }^{137}$

Professors Hillman and O'Rourke also argue that disclosure can spark third-party monitoring, which could, in some cases, improve the content of standard form terms. ${ }^{138}$ Others have defended disclosure when paired with substantive regulation of the architecture in which the information is presented. ${ }^{139}$ But many authors have argued, to the contrary, that disclosure is ineffective in policing terms. ${ }^{140}$ There is substantial empirical research showing that consumers do not read terms of standard form contracts before they agree to them, ${ }^{141}$ and what they read they do not understand. ${ }^{142}$ Thus, mandated transparency provides an illusory form of regulation: it discourages more substantive policing of terms while inundating consumers with information that they cannot, and will not, process. ${ }^{143}$

We suggest recasting this debate around the question of whether or not consumers think that the contract has begun. Our results provide some evidence that whether individuals think they are in a contract influences their self-protective choices. They are more likely to behave in a self-interested way-to protect against exploitation, to contract against breach,

137 Hillman and O'Rourke, $78 \mathrm{U}$ Chi L Rev at 106 (cited in note 17).

138 Id at 107.

139 See, for example, M. Ryan Calo, Against Notice Skepticism in Privacy (and Elsewhere), 87 Notre Dame L Rev 1027, 1062 (2012) (arguing that changes in website design can make reading terms more likely).

140 See, for example, Ben-Shahar and Schneider, $159 \mathrm{U} \mathrm{Pa} \mathrm{L} \mathrm{Rev} \mathrm{at} 651$ (cited in note 16); Ben-Shahar, 5 Eur Rev Contemp $L$ at 13-21 (cited in note 16); Mann and Siebeneicher, 108 Colum L Rev at 998-1001 (cited in note 16).

141 See Hillman and Rachlinski, 77 NYU L Rev at 436 (cited in note 104) ("The consumer, engaging in a rough but reasonable cost-benefit analysis of these factors, understands that the costs of reading, interpreting, and comparing standard terms outweigh any benefits of doing so and therefore chooses not to read the form carefully or even at all."); Florencia Marotta-Wurgler. Will Increased Disclosure Help? Evaluating the Recommendations of the ALIs "Principles of the Law of Software Contracts," $78 \mathrm{U}$ Chi L Rev 165, 173-82 (2011); Florencia Marotta-Wurgler, Does Contract Disclosure Matter?, $168 \mathrm{~J}$ Inst \& Theoretical Econ 94, 108-10 (2012); Ben-Shahar and Schneider, $159 \mathrm{U}$ Pa L Rev at 671-72 (cited in note 16); Yannis Bakos, Florencia Marotta-Wurgler, and David R. Trossen, Does Anyone Read the Fine Print? Testing a Law and Economics Approach to Standard Form Contracts *36-37 (NYU Center for Law, Economics and Organization Working Paper No 09-40, Oct 6, 2009), online at http://papers.ssrn.com/sol3/papers.cfm ?abstract_id=1443256 (visited Mar 3, 2013).

142 See, for example, Alan M. White and Cathy Lesser Mansfield, Literacy and Contract, 13 Stan L \& Pol Rev 233, 237-38 (2002) (explaining that 96 percent of Americans do not have the requisite literacy skills to extract and compute credit cost information from contract and disclosure documents).

143 See Ben-Shahar and Schneider, $159 \mathrm{U} \mathrm{Pa} \mathrm{L}$ Rev at 738-40 (cited in note 16). 
to select trustworthy counterparties-before they believe themselves to have entered a contract. But the subjective moment of contracting only sometimes tracks when a court will find a contract to exist. Parties can intentionally, or unintentionally, manipulate the negotiations to signal contractual agreement in its absence, thus lowering the defenses of their counterparties. ${ }^{144}$

How might they do this? Well, one example comes from Hill itself. As Judge Frank Easterbrook reasoned, terms that follow can be appreciated at leisure rather than requiring a "droning voice [providing contract terms that] would anesthetize rather than enlighten many potential buyers. . . . Customers as a group are better off when vendors skip costly and ineffectual steps such as telephonic recitation, and use instead a simple approveor-return device." ${ }^{145}$ But of course this assumes that consumers are equally likely to protect themselves before and after they understand themselves to be in the contract. If, as we have argued, they are not, then Judge Easterbrook's approach motivates sellers to encourage the belief by buyers that a contract exists-whether or not it does-and then send terms which would not have been agreed to in the first instance.

Even courts that disagreed with Hill adopt its basic understanding of the importance of legal, rather than subjective, formation. Klocek $v$ Gateway, Inc, ${ }^{146}$ which is often paired with Hill in casebooks and treatises, rejects Judge Easterbrook's conclusion that UCC § 2-207 doesn't apply in the absence of two literal forms. ${ }^{147}$ But it apparently would have held that were there evidence from which one could draw an inference of assent from the consumers' receipt of the good, 148 the subsequent terms would have been incorporated in the bargain. ${ }^{149}$ Both courts assume that the psychological reaction to terms that follow ought to be much like the reaction of terms that coincide with bargaining: caveat emptor.

But there is a danger in proceeding this way. A consumer who believes herself to be in a contractual relationship may not protect herself in the same way as a consumer who is still in

144 See notes 104-06, 111. See also Calo, 87 Notre Dame L Rev at 1035-44, 1066-67 (cited in note 139); Ben-Shahar and Schneider, $159 \mathrm{U} \mathrm{Pa} \mathrm{L} \mathrm{Rev} \mathrm{at} \mathrm{696-702} \mathrm{(cited} \mathrm{in} \mathrm{note} \mathrm{16).}$

145 Hill, 105 F3d at 1149.

146104 F Supp 2d 1332 (D Kan 2000).

147 Id at 1339.

148 See Perillo, Contracts $\S 2.18$ at 71 (cited in note 111).

149 See Klocek, 104 F Supp 2d at 1341. See also Rogers v Dell Computer Corp, 138 P3d 826, 831 (Okla 2005). 
negotiations. We should be especially suspicious of terms when the subjective moment of contracting precedes the objective moment, or when there is evidence that one party has encouraged the other to believe that a contract is present when it isn't.

We will illustrate this problem with two additional examples: one a classic chestnut and one from the domain of electronic commerce.

Imagine that Oliver writes Alice and promises to satisfy $\mathrm{Al}$ ice's paper needs for the coming year, the price to be fixed for the first three months, and the parties thereafter to negotiate monthly on the price and quantity required, with a cap at the market bulk standard. ${ }^{150}$ Alice agrees to this deal. After a month, Oliver sends Alice a written "confirmation," which fixes prices for the entire year.

Under traditional contract law principles, the first month of dealing between Alice and Oliver is not a binding contract but rather an agreement to agree, imposing no more than an obligation to negotiate in good faith about future months. ${ }^{151}$ Only the subsequent "confirmation" provided the requisite certainty to permit contractual enforcement. Or to put it differently, had something gone wrong between the parties in that first month, neither likely could have sought contractual recovery. That is so even though Alice probably believed herself to have entered into a morally binding commitment. The agreement-to-agree doctrine thus may subject parties to the risk of exploitation in a way that has not previously been appreciated. Promisees will overinvest in such unenforceable bargains, even though the law provides no recourse at all.

This can be expanded to electronic commerce as well. The traditional distinction between browsewrap and clickwrap gains further substance with our results in mind: Browsewrap terms, which follow an agreement, are less likely to be read than clickwrap terms, which (mildly) precede it. ${ }^{152}$ Courts are more skeptical of browsewrap licenses, generally requiring terms to be conspicuous, while they are generally accepting of clickwrap terms. ${ }^{153}$ If consumers perceive themselves to have entered into

150 For the case on which these facts are loosely based, see Sun Printing \& Publishing Assn v Remington Paper \& Power Co, 139 NE 470, 470 (NY 1923).

151 See Perillo, Contracts $\$ 2.9(a)(4)$ at 53 (cited in note 111).

162 But see Nancy S. Kim, Clicking and Cringing, 86 Or L Rev 797, 848 (2007); Marotta-Wurgler, $168 \mathrm{~J}$ Inst \& Theoretical Econ at 108-10 (cited in note 141).

153 See Kim, 86 Or L Rev at 836-48 (cited in note 152) (summarizing the difference between browsewrap and clickwrap cases). 
a contract by clicking "I agree," this distinction seems entirely warranted. ${ }^{154}$

But what if they don't? After all, a consumer might fairly believe that they have not entered into a contract until a piece of software has finished downloading onto their machine, or when their payment is processed. Or they might believe that the contract occurred when they first clicked on a product to put it into their cart. The point is that the inquiry here isn't about when notice happens with respect to the legal moment of contracting, but when parties subjectively experience that contract as complete. That is an empirical question, which further work could illuminate.

\section{Promissory estoppel.}

When should a disappointed plaintiff be able to bring a promissory estoppel claim? The Restatement (Second) of Contracts requires the plaintiff to prove: (1) the existence of a promise; (2) that the promisor reasonably expected to induce (and indeed did induce) action or forbearance; and (3) the presence of injustice in the absence of enforcement. ${ }^{155}$ Scholars have questioned whether courts should (and do) focus more on the first or second of these requirements. An early set of empirical studies argued that courts focus on the nature of the promise made and ignored the promisee's reliance. ${ }^{156}$ Later work, led by Professor Hillman, suggested that detrimental reliance drove courts; in its absence, recovery was unlikely. ${ }^{157}$ The upshot is a doctrine that is highly controversial, always threatening, but never quite, swallowing up the remains of contract doctrine. ${ }^{158}$ We suggest

154 A more conventional (but related) argument holds that consumers can be induced to enter contracts online without even knowing that they are doing so, as the process lacks the ordinary off-line formalities. Becher, $68 \mathrm{La} \mathrm{L} \mathrm{Rev} \mathrm{at} \mathrm{164-66} \mathrm{(cited} \mathrm{in} \mathrm{note} \mathrm{92).}$

155 Restatement (Second) of Contracts $\$ 90$.

156 See, for example, Daniel A. Farber and John H. Matheson, Beyond Promissory Estoppel: Contract Law and the "Invisible Handshake," 52 U Chi L Rev 903, 929-30 (1985); Edward Yorio and Steve Thel, The Promissory Basis of Section 90, 101 Yale L J $111,129-30$ (1991).

157 Robert A. Hillman, Questioning the "New Consensus" on Promissory Estoppel: An Empirical and Theoretical Study, 98 Colum L Rev 580, 618 (1998). See also Jimenez, 57 UCLA L Rev at 701-02 (cited in note 2) (arguing that courts justify themselves in terms of both promise and reliance).

158 See Charles L. Knapp, Reliance in the Revised Restatement: The Proliferation of Promissory Estoppel, 81 Colum L Rev 52, 53 (1981) ("[P]romissory estoppel ... has become perhaps the most radical and expansive development of this century in the law of promissory liability.") (quotation marks omitted); Grant Gilmore, The Death of Contract 64-76 (Ohio State 1974). 
that the law of promissory estoppel, like terms that follow later, ought to be understood in light of the promisee's understanding of the contract's legal effect. Promisees who believe that they are party to enforceable contracts cannot be relied upon to protect themselves.

In a previous article, we argued that promissory estoppel's continued controversial nature might result from its distance from commonsense moral understanding of what makes breach of contract feel immoral. We explained that contractual breach could result in a feeling of being a "sucker"-one who was the victim of an intentional and exploitative decision to betray a relationship. ${ }^{159}$ Promissory estoppel, by contrast, focuses generally on the promisor's state of mind (her belief that the promise would or would not lead to reliance) ${ }^{160}$ and does not require the betrayal of an agreement that inspired trust. ${ }^{161}$ Thus, we concluded that "promissory estoppel cases seem less likely to contain plaintiffs who expected the psychological feeling of being suckered." 162 A more realistic promissory estoppel doctrine would start with the promisee's subjective understanding, asking if he subjectively believed the promise was legally enforceable. Our results suggest how this approach, apparent in some cases, ${ }^{163}$ could reorient doctrine toward those promisees who were led to believe that they were in bargains, thus lowering their defenses to exploitation.

The consequence of this changed orientation would be a doctrine that focused on the promisor's efforts to lead the promisee on and the promisee's own belief that she was in a legally enforceable contract. Consider-in this light-the famous case of Hoffman $v$ Red Owl Stores, Inc. ${ }^{164}$ Hoffman may be an outlier case in its suggestion that parties will routinely win back their reliance costs in promissory estoppel actions in the absence of

159 Tess Wilkinson-Ryan and David A. Hoffman, Breach Is for Suckers, 63 Vand L Rev 1003, 1039-40 (2010).

160 See Restatement (Second) of Contracts $\S 90$ (making enforceable a promise that the "promisor should reasonably expect to induce action or forbearance") (emphasis added); Stewart v Cendant Mobility Services Corp, 837 A2d 736, 742 (Conn 2003).

161 See John J. Chung, Promissory Estoppel and the Protection of Interpersonal Trust, 56 Cleve St L Rev 37, 50-51 (2008) (discussing the differences between trust and reliance).

162 Wilkinson-Ryan and Hoffman, 63 Vand L Rev at 1040 (cited in note 159).

163 See Sidney W. DeLong, The New Requirement of Enforcement Reliance in Commercial Promissory Estoppel: Section 90 as Catch-22, 1997 Wis L Rev 943, 959 (noting that some courts suggest that promisees must demonstrate that they believed a promise legally enforceable to obtain relief under § 90).

$164133 \mathrm{NW} 2 \mathrm{~d} 267$ (Wis 1965). 
any mutual agreement between the parties. ${ }^{165}$ But we suggest that conventional treatments of the case may be too quick to dismiss Hoffman's claim and the court's outcome. In Hoffman, Red Owl (the promisor) allegedly told Hoffman that his $\$ 18,000$ proposed investment in their franchise would not be a problem. ${ }^{166}$ If Hoffman believed that this response constituted a contractual commitment-even though it clearly was not one in the law's eyes-his later reliance might be more easily explained and defended. Directing the law to ask directly about his subjective understanding of the promise might not be an ideal solution. ${ }^{187}$ But it would have the previously unexamined virtue of foregrounding the vulnerability that the subjective experience of being in a contract creates in lay promisees.

\section{Limitations}

Our study is subject to several limitations and possible criticisms. We discuss concerns regarding the scope of our findings, criticisms common to all survey research, the representativeness of our survey population, and the utility of examining lay psychology in contract law.

Our response measures were either general attitudinal scales or prompts asking subjects for their hypothetical willingness to pay (or accept) money. A typical concern with such research is that survey respondents without real monetary incentives will overstate their commitment to contracting, so as to signal that they are the kind of person who keeps promises. ${ }^{168}$ Of course there is considerable literature that finds, to the contrary, that attitudinal scales accurately predict behavior. ${ }^{169}$ But in real-world contracts with more at stake, individuals may tend to behave in a more economically maximizing manner. Perhaps subjects in our experiments were motivated to demonstrate how

165 For an extended argument against the Hoffman holding and against treating it as a typical promissory estoppel case, see Robert E. Scott, Hoffman v. Red Owl Stores and the Myth of Precontractual Reliance, in Douglas G. Baird, ed, Contracts Stories 62, 82 (Foundation 2007).

166 Hoffman, 133 NW2d at 269.

167 For example, testimony about subjective belief may be unreliable and thus lead to jury confusion.

168 For a discussion of why survey responses might not track actual behavior, see Guthrie, $97 \mathrm{Nw}$ U L Rev at 1156-59 (cited in note 71) (discussing external validity concerns typical of prospect theory research); Yuval Feldman, Attitudes and Behavior, in David S. Clark, ed, Encyclopedia of Law \& Society: American and Global Perspectives 102, 102-04 (Sage 2007) (discussing concerns with survey experiments).

169 See Feldman and Teichman, 100 Georgetown L J at $46 \&$ n 209 (cited in note 92). 
important mere contract status was to them, and thus were even less likely to purchase precautions against breach. Further work, which triangulates across survey populations, including laboratory games, real-money stimuli, and distinctive counterparties, could help build confidence in our findings. ${ }^{170}$

Our two subject pools pose distinct questions about bias. Studies 1 and 2 were conducted on respondents drawn from workers at Amazon Mechanical Turk. Recent research on Amazon Mechanical Turk subjects has found them to be significantly more representative of the general population than the ordinary undergraduate samples. ${ }^{171}$ However, women are generally overrepresented-as we found-and subjects are slightly better educated than the population mean. ${ }^{172}$ This could raise concerns. In other areas of study, women and men exhibit different risk preferences (especially regarding financial risk). ${ }^{173}$ However, we found no meaningful gender differences in responses. A more pressing concern is that subjects recruited online to complete surveys may lack motivation to pay attention to the task. ${ }^{174}$ In our work, we dropped respondents who completed their tasks in a very short period of time or who skipped questions, but future work could incorporate more robust manipulation checks against inattentive participants. ${ }^{175}$

With respect to Study 3, which studied incoming law students, we face a different set of questions. Some have argued that individuals trained in law may be more attentive to the legal remedies surrounding contracting and/or less sensitive to the

170 See, for example, Dan Simon, In Praise of Pedantic Eclecticism: Pitfalls and Opportunities in the Psychology of Judging, in David Klein and Gregory Mitchell, eds, The Psychology of Judicial Decision Making 131, 143 (Oxford 2010).

171 See, for example, Gabriele Paolacci, Jesse Chandler, and Panagiotis G. Ipeirotis, Running Experiments on Amazon Mechanical Turk, 5 Judgment \& Dec Making 411, 415-17 (2010); David G. Rand, The Promise of Mechanical Turk: How Online Labor Markets Can Help Theorists Run Behavioral Experiments, 299 J Theoretical Bio 172, 175-76 (2012).

172 Paolacci, Chandler, and Ipeirotis, 5 Judgment \& Dec Making at 412 (cited in note 171).

173 See Brad M. Barber and Terrance Odean, Boys Will Be Boys: Gender, Overconfidence, and Common Stock Investment, 116 Q J Econ 261, 264-66 (2001) (summarizing studies that find that men are more risk seeking than women).

174 See Paolacci, Chandler, and Ipeirotis, 5 Judgment \& Dec Making at 412-13 (cited in note 171) (surveying various motivations that Mechanical Turk users gave for using the service and noting that 32.3 percent said they used it for "killing time").

175 See Daniel M. Oppenheimer, Tom Meyvis, and Nicolas Davidenko, Instructional Manipulation Checks: Detecting Satisficing to Increase Statistical Power, 45 J Exp Soc Psych 867, 869-70 (2009). 
expressive power of contracting. ${ }^{176}$ Our subjects, who were recruited in the first week of their orientation, are unlikely to be similarly biased by legal doctrine. ${ }^{177}$ Anecdotally, law students are more risk averse than the population at large, and thus possibly more likely to purchase precautions against breach. It seems unlikely, however, that this effect would be mediated by being in a contract.

A different external validity objection presents in response to papers about contracts in particular. As the relational contracting school famously illustrated, contracting behavior by commercial parties can wildly unsettle prior expectations about the importance of law and legal rules. ${ }^{178}$ Thus, the argument goes, we ought to focus experimental work on the agents of sophisticated commercial parties, who are likely to be repeat players in contract litigation. For example, Professors Daniel Markovits and Alan Schwartz, defending the primacy of the expectation interest, argued recently that experiments like the ones presented in this Article ought to be discounted in part because they study "individual persons, not firms. A firm is more likely to exhibit behavior consistent with the maximization of monetary returns than an individual responding to a questionnaire." 179

We agree and disagree with this critique. It is quite useful to study the behavior of sophisticated commercial parties engaging in contracting - contract law gained immensely from the insights of the Wisconsin School.180 Bringing such parties into the laboratory, though logistically quite challenging, holds real

176 See, for example, Feldman and Teichman, 100 Georgetown $\mathrm{L} J$ at 47 (cited in note 92).

177 In an interesting experiment, Professors Raymond Fisman, Shachar Kariv, and Daniel Markovits observe that even one semester's worth of law school education may change students' distributional preferences in the Dictator Game, a game in which one player (the dictator) is free to divide a sum of money with another player however she sees fit. See Raymond Fisman, Shachar Kariv, and Daniel Markovits, Exposure to Ideology and Distributional Preferences *3-4 (working paper, July 19, 2009), online at http:// emlab.berkeley.edu/ kariv/FKM_I.pdf (visited Mar 3, 2013).

178 See, for example, Macaulay, 28 Am Soc Rev at 55 (cited in note 85); Daniel Keating, Exploring the Battle of the Forms in Action, 98 Mich L Rev 2678, 2695-2704 (2000); Russell J. Weintraub, $A$ Survey of Contract Practice and Policy, 1992 Wis L Rev 1, 13-30.

179 Daniel Markovits and Alan Schwartz, The Myth of Efficient Breach: New Defenses of the Expectation Interest, $97 \mathrm{Va}$ L Rev 1939, $1954 \mathrm{n} 32$ (2011).

180 David V. Snyder, The Law of Contract and the Concept of Change: Public and Private Attempts to Regulate Modification, Waiver, and Estoppel, 1999 Wis L Rev 607, 654. 
promise in expanding the burgeoning literature relating to professionalism, agency, and behavior. ${ }^{181}$

However, this argument cuts both ways. We note first that the extant literature has focused on how. post-trial remedies will influence pre-breach precautionary behavior. That is, the literature assumes that almost all contracts are litigable. But in the kinds of contracts that are the subject of our experimental series, the availability of damage remedies for breach is practically irrelevant. No one will sue, or recover, in a contracts case with so little at stake outside the rough justice of small claims court. And, only moderately less controversially, even if these contracts were large enough to make suits economically worthwhile, lawsuits by individuals are likely to be driven by reputational and emotional factors that aren't easy to predict ex ante. ${ }^{182}$ Thus, though studying the agents of repeat, commercially sophisticated parties is quite useful, it will not tell us much about the behavior of lay players in typical consumer contracts, who are unlikely to ever experience contract remedies in action. ${ }^{183}$

More generally, simply because the contracts we have described aren't likely to be litigated does not mean that they shouldn't bear on the makeup of doctrine. The theory of default rules rests on assumptions about the behavior of legally unsophisticated members of the population-both majoritarian and information-forcing penalty defaults, for instance, rest on (sometimes) informed guesses about the views of the population mean. ${ }^{184}$ As we described above, our understanding of offer and acceptance, promissory estoppel, and modification similarly rests on intuitions about how "ordinary" people will behave. That those individuals will almost never actually show up to court to testify about their precontracting intuitions doesn't mean that such intuitions ought to be discounted. Indeed, it is a

181 See Chris Guthrie and Jeffrey J. Rachlinski, Insurers, Illusions of Judgment \& Litigation, 59 Vand L Rev 2017, 2047 (2006) (reporting that decision makers at insurance firms were less prone to anchoring, framing, and self-serving biases).

182 As an example, it's well established that certain kinds of apologies will provoke settlements, though such apologies must be perceived to be genuine to be effective. See Jennifer K. Robbennolt, Apologies and Legal Settlement: An Empirical Examination, 102 Mich L Rev 460, 482-90 (2003) (finding that the acceptance rate for settlements increased from 52 percent under no apology to 73 percent under a full apology).

183 This is not to say that they might not learn about such remedies indirectly through the actions of creditors for example. Consider Mark P. Gergen, A Theory of Self-Help Remedies in Contract, 89 BU L Rev 1397, 1397-1401 (2009) (discussing self-help rules).

184 See, for example, George S. Geis, Empirically Assessing Hadley v. Baxendale, 32 Fla St U L Rev 897, 921-49 (2005). 
mark against the current literature on precautions that it focuses so heavily on how promisees and promisors will react to damage measures, when those remedies are unlikely to be known, appreciated, or experienced by the vast majority of individuals participating in commercial life.

Finally, some have argued that legal rules, if they drift too far from common moral intuitions, would come to be seen as illegitimate and thus less likely to influence behavior. ${ }^{185}$ This literature is admittedly controversial. ${ }^{186}$ However, if it is the case that if individuals were to come to believe that common contracting rules were written exclusively to respond to the views of sophisticated, repeat-player commercial parties, then it is possible that they would come to distrust the rules that resulted from such elite inquiries. Indeed, doctrine would likely come to be seen as the product of capture, or, in layman's terms, corruption. Courts ought to be at least informed of how ordinary, legally naive citizens think about the kinds of contracts they typically enter into. What they do with such knowledge is another matter entirely.

\section{CONCLUSION}

Everyone knows that contract parties behave differently toward one another than do strangers. The question is why. The dominant paradigm in contract theory assumes that parties, forecasting their remedies with impressive precision, tailor their investment in the bargain and their behavior optimally to maximize their individual gains. This may be explained conventionally by transaction costs or forecasted remedies following legally enforceable bargains. Another possibility is that the moment of contracting resets the status quo and primes a cognitive script that favors trust in contract. This reframed understanding of self-protective behavior by promisees might help us to reorient some important questions in current doctrine. We are hopeful that this is the first step in the larger project of understanding

185 See, for example, Paul H. Robinson and John M. Darley, Intuitions of Justice: Implications for Criminal Law and Justice Policy, $81 \mathrm{~S}$ Cal L Rev 1, 18-31 (2007).

186 See, for example, Christopher Slobogin, Some Hypotheses about Empirical Desert, 42 Ariz St L J 1189, 1193-98 (2011) (arguing that individuals either won't notice a departure from ordinary intuitions about punishment or won't care). See also Donald Braman, Dan M. Kahan, and David A. Hoffman, Some Realism about Punishment Naturalism, 77 U Chi L Rev 1531, 1566-68 (2010) (arguing that individuals' views about the morality of punishment are culturally contingent). 
why, and when, individuals surrender their armor and treat their contracts as partnerships. 


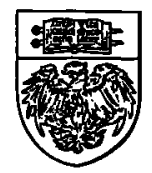

